Portland State University

PDXScholar

Dissertations and Theses

Dissertations and Theses

1980

Normative data on the Auditory memory test battery

Mary Clare Mountain

Portland State University

Follow this and additional works at: https://pdxscholar.library.pdx.edu/open_access_etds

Part of the Cognitive Psychology Commons, and the Speech Pathology and Audiology Commons Let us know how access to this document benefits you.

Recommended Citation

Mountain, Mary Clare, "Normative data on the Auditory memory test battery" (1980). Dissertations and Theses. Paper 2982.

https://doi.org/10.15760/etd.2976

This Thesis is brought to you for free and open access. It has been accepted for inclusion in Dissertations and Theses by an authorized administrator of PDXScholar. Please contact us if we can make this document more accessible: pdxscholar@pdx.edu. 
AN ABSTRACT OF THE THESIS OF Mary Clare Mountain for the Master of Science in Speech Communication; Emphas is Speech Pathology/Audiology presented May 6, 1980.

Title: Normative Data on the Auditory Memory Test Battery.

APPROVED BY MEMBERS OF THE THESIS COMMITTEE:

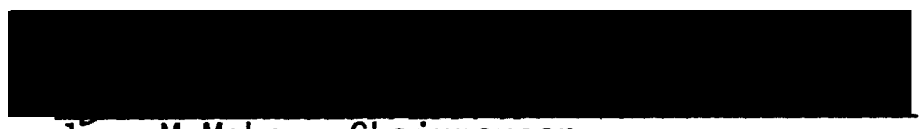

Joan McMahon, Chairperson

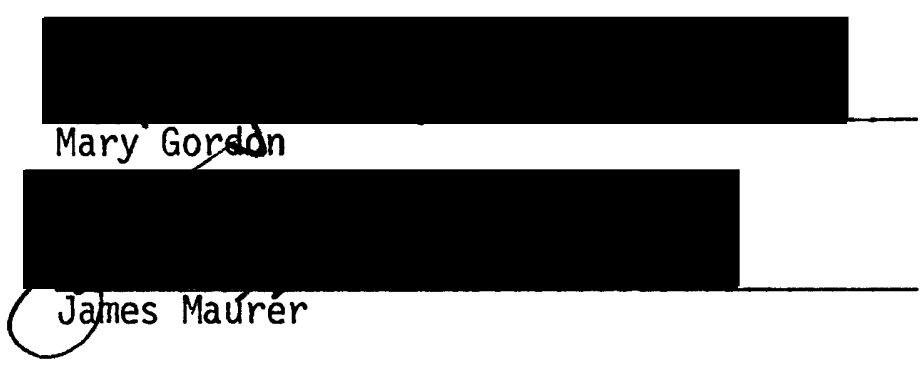

This study examined the means and standard deviations for the Auditory Memory Test Battery (Burford, 1976) using a sample of normal second, third, and fourth grade children. The study also compared span and sequence scores, low and high SES scores, and an individual's test scores with teacher judgment of intelligence group. A brief examination of the AMTB as used with LD children was also performed but not included in the statistical analysis.

A total of seventy-five normal subjects were tested individually using the AMTB. The AMTB consisted of five tape recorded tests of recall for digits, related words, unrelated words, sentences, and nonsense words. Subjects responded to randomly presented tests and each subject obtained ten scores: a span score and a sequence score for each of the 
five subtests. The possible score for each subtest was twenty-eight points for both span and sequence. Two learning disabled children were also tested using the AMTB for comparative purposes.

The results of this investigation revealed a plateauing effect for auditory STM. Scores for second and third graders were fairly equal while fourth graders scored better than the other two grade levels. A developmental change in auditory memory appeared to take place at the fourth grade level.

Answers to corollary questions revealed the following results. Scores for span were significantly better than scores for sequence among this group of normal children. Scores for children from a low SES were almost identical to scores for children from a high SES. A tendency for higher scores among those children judged to be of a "high" intelligence group was noted.

The two LD children tested scored well below the normal mean on all subtests except Nonsense Words. Errors were qualitatively different from those of normal children. 


\title{
NORMATIVE DATA ON THE AUDITORY \\ MEMORY TEST BATTERY
}

by

MARY CLARE MOUNTAIN A thesis submitted in partial fulfiliment of the
requirements for the degree of

\author{
MASTER OF SCIENCE IN SPEECH COMMUNICATION \\ with an emphasis in \\ SPEECH PATHOLOGY/AUDIOLOGY
}

Portland State University

1980 
TO THE OFFICE OF GRADUATE STUDIES AND RESEARCH:

The members of the Committee approve the thesis of Mary Clare Mountain presented May 6, 1980.

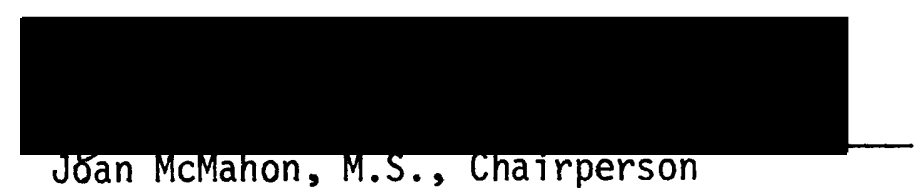

Jzan McMahon, M.S., Chairperson

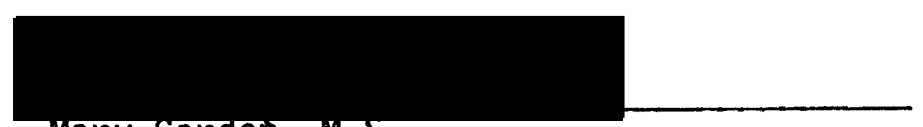

Mary Gordes, M.S.
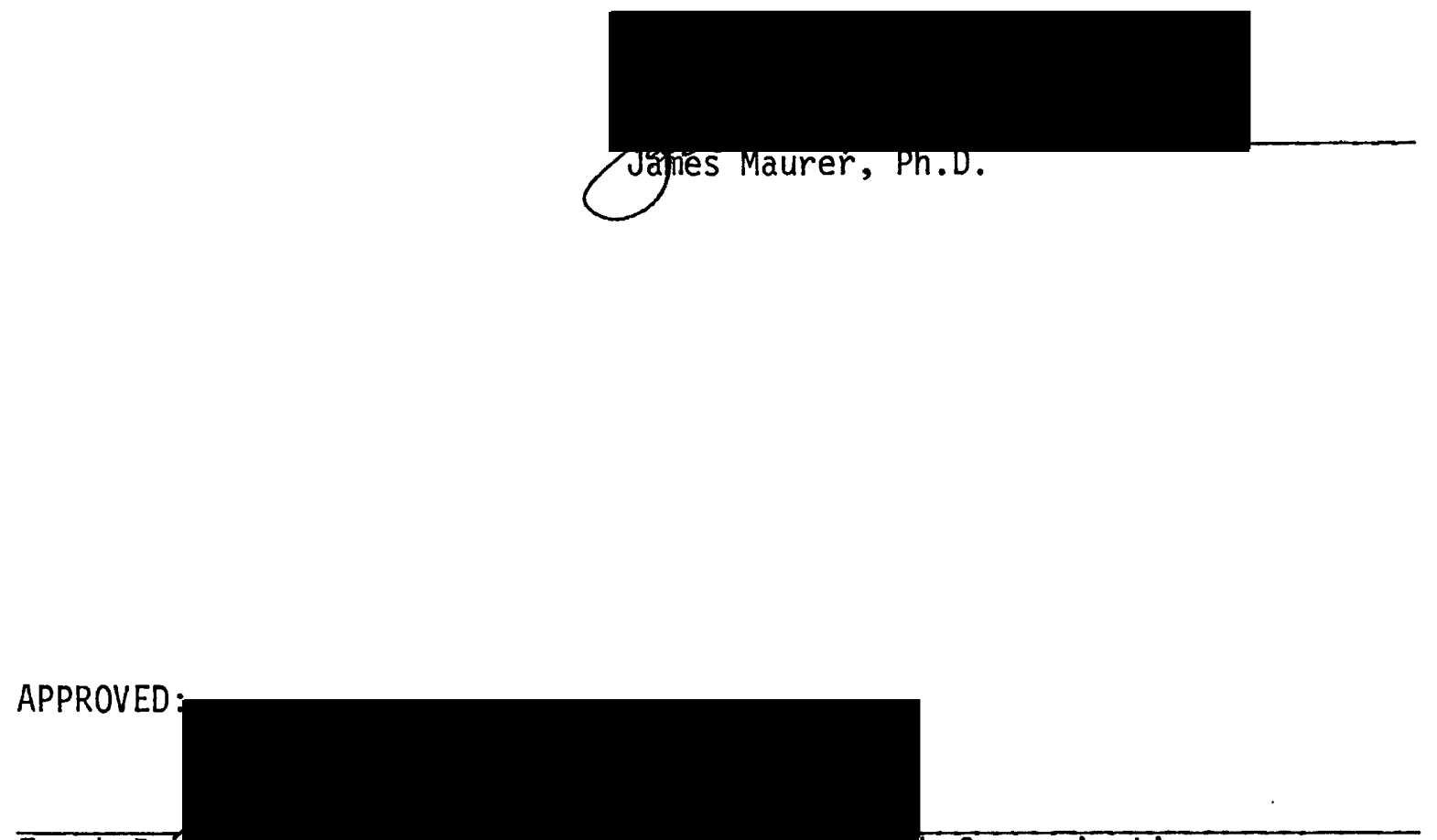

Frank Roberts, Acting Head, Department of speech Communication

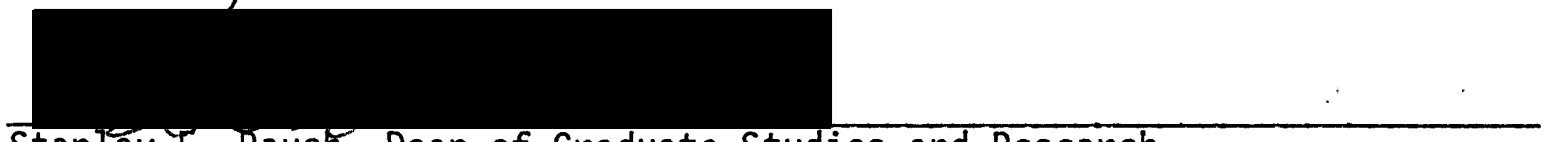

Stanley E. Rauch, Dean of Graduate Studies and Research 


\section{ACKNOWLEDGMENTS}

Since I cannot adequately express my gratitude in this small space, let me simply say thank you to Joan McMahon, Mary Gordon, Dr. James Maurer, and Lance Tsugawa. I offer a special thank you to Larry Selivanow, and it is to him that I dedicate this opus. 
TABLE OF CONTENTS

PAGE

ACKNOWLEDGMENTS

LIST OF TABLES

LIST OF FIGURES

CHAPTER

I INTRODUCTION AND STATEMENT OF PURPOSE . . . . . .

Introduction .................

Statement of Purpose ........... 3

II REVIEW OF THE LITERATURE .............. . . 4

Introduction to Memory .......... 4

Auditory Memory and Speech/Language

Development ............. . .

Auditory STM and the Learning Disabled

Child

Summary .............. . . 20

III METHODS AND PROCEDURES ................ 21

Subjects................ 21

Instrumentation ............ 22

Tes.t Administration ......... . . 23

Scoring Procedures............ 24

Data Analysis ............ . . . 26 26

IV RESULTS AND DISCUSSION ................... 28

Results ................. 28 
CHAPTER

PAGE

Discussion . . . . . . . . . . . . 37

V SUMMARY AND IMPLICATIONS . . . . . . . . . . . 41

Summary ................... . . 41

Implications . . . . . . . . . . . . . 42

SELECTED BIBLIOGRAPHY . . . . . . . . . . . . . . . . . . . 44

APPENDICES . . . . . . . . . . . . . . . . . . . . . . 47 


\section{LIST OF TABLES}

TABLE

PAGE

I Means and Standard Deviations for Three Grade

Levels on the AMTB .............

II Statistical Comparisons Between Grade Levels

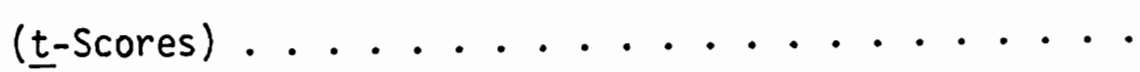

III Statistical Comparisons Between Span and Sequence Scores (t-Scores) . . . . . . . .

IV Comparison Between Scores for Low SES and High

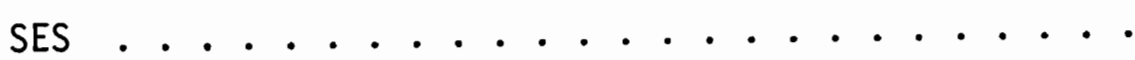

V Comparison Between Subtest Scores and Intelligence Groups (Second Grade) ............. .

VI Comparison Between Subtest Scores and Intelligence Groups (Third Grade) . . . . . . . . .

VII Comparison Between Subtest Scores and Intelligence Groups (Fourth Grade) .............

VIII Comparison Between Means for Normal and LD

Second Graders . . . . . . . . . . . . . 


\section{LIST OF FIGURES}

FIGURE

PAGE

1. The Dual-Stage Model of Memory . . . . . . . . . . 8

2. Dual-Stage Model Emphasizing Short-Term Store . . . . . 8

3. Retrieval Model ............... 10

4. Model Including Immediate Memory . . . . . . . . . . 12 


\section{CHAPTER I}

\section{INTRODUCTION AND STATEMENT OF PURPOSE}

\section{Introduction}

A functioning memory system proves essential to the well-being of the individuat. The memory is inextricably bound to intelligence. Piaget and Inhelder (1973) stated that intelligence is retained via the memory and that the two factors evolve along identical successive frameworks, thus yielding a unified system. The individual further depends on the memory for the development of a communication system. All aspects of the memory are drawn upon as intelligence and communication coalesce within the individual. Both short-term memory and the long-term memory are tapped in the developmental process along with involvement of the dual modalities of vision and audition. While all aspects of memory play a part in this development, the present study will focus on the specific role of auditory short-term memory.

Auditory short-term memory (STM) has been termed critical for speech and language development (Johnson and Mykelbust, 1967). The auditory STM includes the two sub-skills of span (the number of stimuli retained) and sequence (the retention of stimuli in serial order). Witkin (1971) outlined the importance of both of these factors to speech and language development. She stated that auditory memory span is necessary to make judgments as to whether two or more speech sounds are alike or different. Sequencing is important since words and sentences are made up of sounds 
presented in a temporal order.

Malfunctioning of the auditory STM may result in the delay or disorder of speech and language development. Children with specific learning disabilities have been observed to be unable to recall or reproduce a sequence of numbers, letters, or non-meaningful symbols (McCarthy and MCCarthy, 1969). It has been suggested that the auditory STM is actually a diagnostic parameter for the identification of a child with a learning disability (Kirk, McCarthy, and Kirk, 1968).

Tests of auditory STM have classically utilized a digit repetition task (Wechsler, 1974). The validity of this limited task as a determiner of the functioning of the auditory STM has been questioned (Wiig and Seme1, 1976). Kirk, McCarthy, and Kirk (1968) attempted to "improve" the digit repetition task somewhat by structuring the task so that digits were presented at $\frac{3}{2}$ second intervals as opposed to the usual 1 second interval. They determined that the $\frac{1}{2}$ second interval was more sensitive to auditory memory deficits (Wiig and Seme1, 1976).

Further issues exist in the auditory memory testing area. Some experimenters have suggested that tests for span and sequence may be used interchangeably (Turiads, Wepman, and Morency, 1972). Another issue is that of the use of stimulus types other than, or in addition to, digits (Aten and Davis, 1968; Berry, 1969). Burford (1976) developed the Auditory Memory Test Battery (AMTB) to resolve the above-mentioned auditory memory testing issues. Her battery systemmatically examined the attributes of span and sequence while utilizing five stimulus types: digits; unrelated words; related words; sentences; and, nonsense words. Burford found a significant difference between scores for span and scores for sequence on only the Digit subtest. She suggested further study on 
this issue as an implication of her research. Though Burford's test was comprehensive and systemmatic, it was never standardized. To be utilized as a diagnostic tool, standardization of the test is prerequisite. One must first be aware of the performance of normal children to be able to determine "disordered" performance (Casteel, 1978). Therefore, the present study sought to provide normative data on the AMTB as developed by Burford (1976) so that the test might gain clinical applicability.

\section{Statement of Purpose}

The purpose of this study was to investigate the AMTB using a sample of normal children of a low-to-middle economic range from the Scappoose, Oregon School District. The attributes of memory span and sequence were examined using the following stimulus types: digits; unrelated words; related words; sentences; and, nonsense words. The investigation sought to answer the following question:

What are the means and standard deviations for each of three grade levels (second, third, fourth) on the AMTB?

Corollary questions included the following:

1) Is there a statistically significant difference between scores for span and scores for sequence on the AMTB?

2) How do test results drawn from a low-to-middle economic area compare with those drawn from a middle-to-high economic area?

3) How do test scores compare with teacher judgments of a child's intelligence grouping (low, middle, high)? 


\section{CHAPTER II}

\section{REVIEW OF THE LITERATURE}

The study of memory is complicated by the presence of many and varied theories, and the lack of hard evidence at all levels. The very term memory proves to be a nebulous one. Hunter (1964) indicated that memory is often discussed as an object one possesses when, in reality, it is an abstraction referring to the activity of learning or remembering. Chalfant and Scheffelin (1969) concurred on the ambiguity of the term memory since it is applied to both the process and the product. They defined the term as the ability to retain, recall, and recognize representations of past experiences. For the purpose of this study, the Chalfant and Scheffelin definition will be operationally accepted.

\section{Introduction to Memory}

Memory as Physiological Activity

Memory may be discussed in terms of physiological change, location of memory processing, and the process itself. In examining the physiological changes taking place during the memory process, Hilgard and Bower (1975) delineated two different views. Proponents of the "dynamic" view postulate that stimuli cause continuing electrical activity in neural circuits. As long as the circuits are activated, memory will persist. Supporters of the alternate view, the "structural" view, indicate that actual physical, structural, or biochemical changes take place in the nervous system during the memory process. Memory will persist 
even though the original neuronal circuits are no longer activated. Hilgard and Bower supported the structural view since the dynamic view could be disproven fairly easily, e.g., the electrical "brain storms" of a grand mal epileptic seizure do not result in the loss of memory. A specific structural view was proposed by Chapouthier (1973). He addressed a molecular basis for memory and indicated that since innate information is stored in the DNA molecule, perhaps the "memory" of some event is also stored chemically. Chapouthier examined animal research which outlined changes in nucleic acids and proteins following learning. He concluded that quantitative and qualitative differences in the RNA and protein contents of the brain were evidenced. However, he cautioned that it was not specified if these changes resulted from the learning itself, or from a nonspecific increase in brain metabolism. He indicated that RNA and protein synthesis do appear to play a role in the early stage of memory consolidation.

To further support his molecular theory of memory, Chapouthier (1973) referred to bioassay methods by which chemicals are withdrawn from the brain of a trained animal and injected into the brain of a naive anima1. Research indicated that there was a formation of peptides in the brain during learning. Peptides were demonstrated to alter the behavior of recipient animals when injected in sufficient doses, i.e., the recipient animal could then make a discrimination that the donor animal had been trained to make. This evidence would seem to suggest chemical alterations taking place during the memory process. However, as Chapouthier cautioned, much research is necessary to pinpoint the actual chemical changes that can be directly attributed to learning and memory. Until such work is done, the molecular concept remains a very hypothetical one, 
and other theories cannot be discounted.

\section{Location of the Memory Process}

Yet another theoretical area in regard to memory involves the concept of the location of the memory process. Is the entire central nervous system involved? Are there areas of specialization? Penfield and Rasmussen (1955) noted the importance of the temporal cortex to the memory process. They deduced that the temporal cortex was essential to the process of remembering and interpreting things seen and heard. When Penfield and Rasmussen stimulated the temporal cortex with electrodes, visual, auditory, or combined memories were brought to the patient's consciousness. Such experimentation led Penfield and Rasmussen to the conclusion that the original memory pattern was formed in the temporal cortex. This original memory pattern was comprised of information that came to the attention of the patient and was then filed in the temporal cortex.

Iversen (1973) reviewed brain lesion/memory research pertaining to animals with damage in the frontal and temporal lobes. She indicated that the memory impairments found in these two groups (frontals and temporals) were remarkably similar. She concluded that although a single memory substrate was involved in tested tasks, perhaps the memory process is widely distributed in the central nervous system and is therefore disrupted by damage to any part of the brain. As with other memory controversies, the issue of localization remains unresolved.

Memory Process: Short and Long-Term Memory

A final theoretical issue is that of the memory process. Vastly divergent views concerning process have been proposed and, as Piaget and 
Inhelder (1973) suggested, there is "room for every conceivable hypothesis." Individuals have attempted to look inside the "black box" of memory and to determine how the system functions. The "classical" view of memory as reported by Chalfant and Scheffel in (1969) supported the idea that all inputs were stored in a form such that they could be retrieved as stored. A direct, one-stage storage and retrieval process was implied by the classical view.

Theory in the area of process has progressed beyond the classical view. Currentiy, the most widely held theory of the memory process is the dual-stage model (see Figure 1). Iversen (1973) explained that according to this model, the complete representation of the input is held for a very short period of time (less than $200 \mathrm{msec}$ ) in the sensory register. A proportion of the incoming information is then held and re-circulated by the short-term memory mechanism. At this time, a copying or transfer process results in a long-term trace which strengthens over a period of time and becomes relatively permanent. The transfer to the long-term memory will be discussed further in terms of a specific model.

Memory Process: Importance of the Short-Term Memory

Atkinson and Shiffrin (1971) suggested a more specific dual-stage model of the memory process (see figure 2). Through this model, the authors emphasized the importance of the short-term memory which is under the immediate control of the subject and governs the flow of information into the memory system. To delineate the importance of the short-term memory, or short-term store in the authors' language, Atkinson and Shiffrin discussed the control processes which exist in the short-term store. 


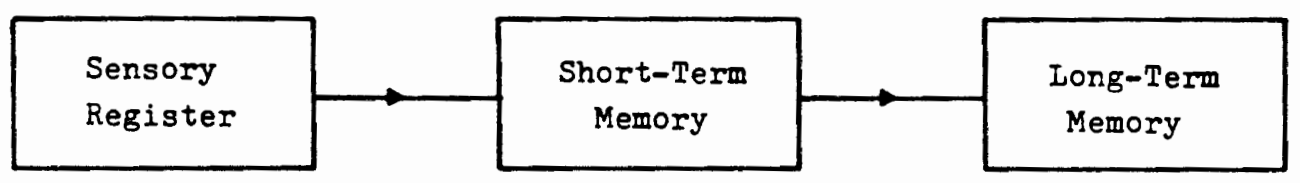

Figure 1. The dual-stage model of memory (Iversen, 1973).

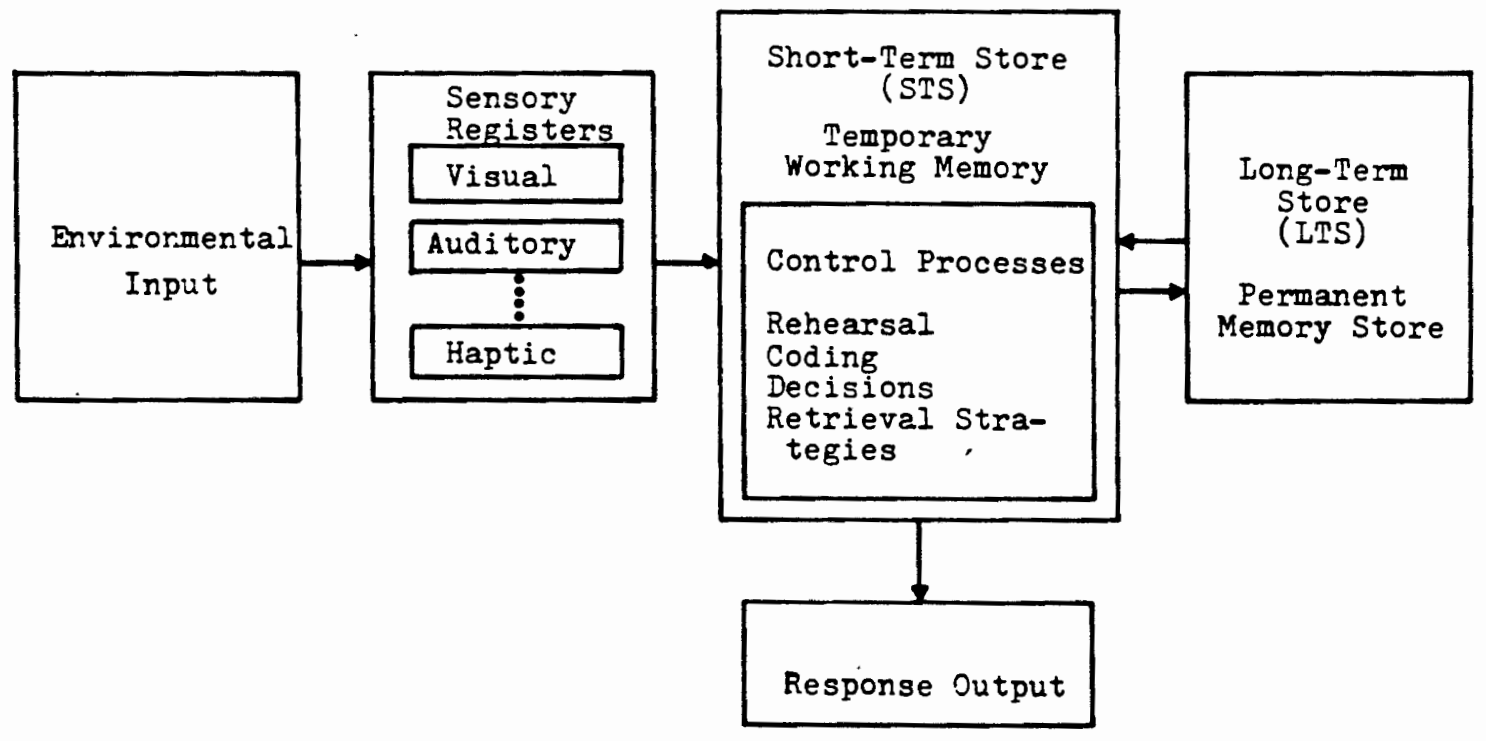

Figure 2. Dual-stage model emphasizing short-term store (Atkinson and Shiffrin, 1971). 
1) Rehearsal--repeating information, overtiy or covertly.

2) Coding--putting information into a context of additional, easily retrievable information such as a mnemonic phrase or sentence.

3) Imaging--remembering information through visual images. Atkinson and Shiffrin stressed that these control processes are operational, i.e., selected at the individual's discretion. The choice of one control process over another is situation-specific. However, the authors indicated that rehearsal is the most important and the most frequently used control process.

The flow of information in the Atkinson and Shiffrin (1971) model is much the same as in the basic model outlined above by Iversen (1973), but storage and retrieval actions are more clearly defined. Information is stored by way of a transfer from the short-term store (STS) to the long-term store (LTS). Atkinson and Shiffrin postulated that transfer is a function of the amount of time information remains in the "rehearsal buffer" of the STS. The longer the time, the more rehearsal, and the greater the transfer. Information may be lost from the STS because of the interference of competing stimuli during the intervening interval. The STS also plays an important role in retrieval. Atkinson and Shiffrin stated that to retrieve information from the LTS, one must find access to it. This is accomplished when an individual activates a likely subset of information, places it in the STS, and scans for the desired image. If one subset does not yield the desired information, another subset is chosen and utilized in the scanning process (see Figure 3 ).

According to the Atkinson and Shiffrin (1971) model, the short-term memory plays a vital role in the total memory process. After reviewing animal brain lesion studies, Iversen (1973) altered the Atkinson and 


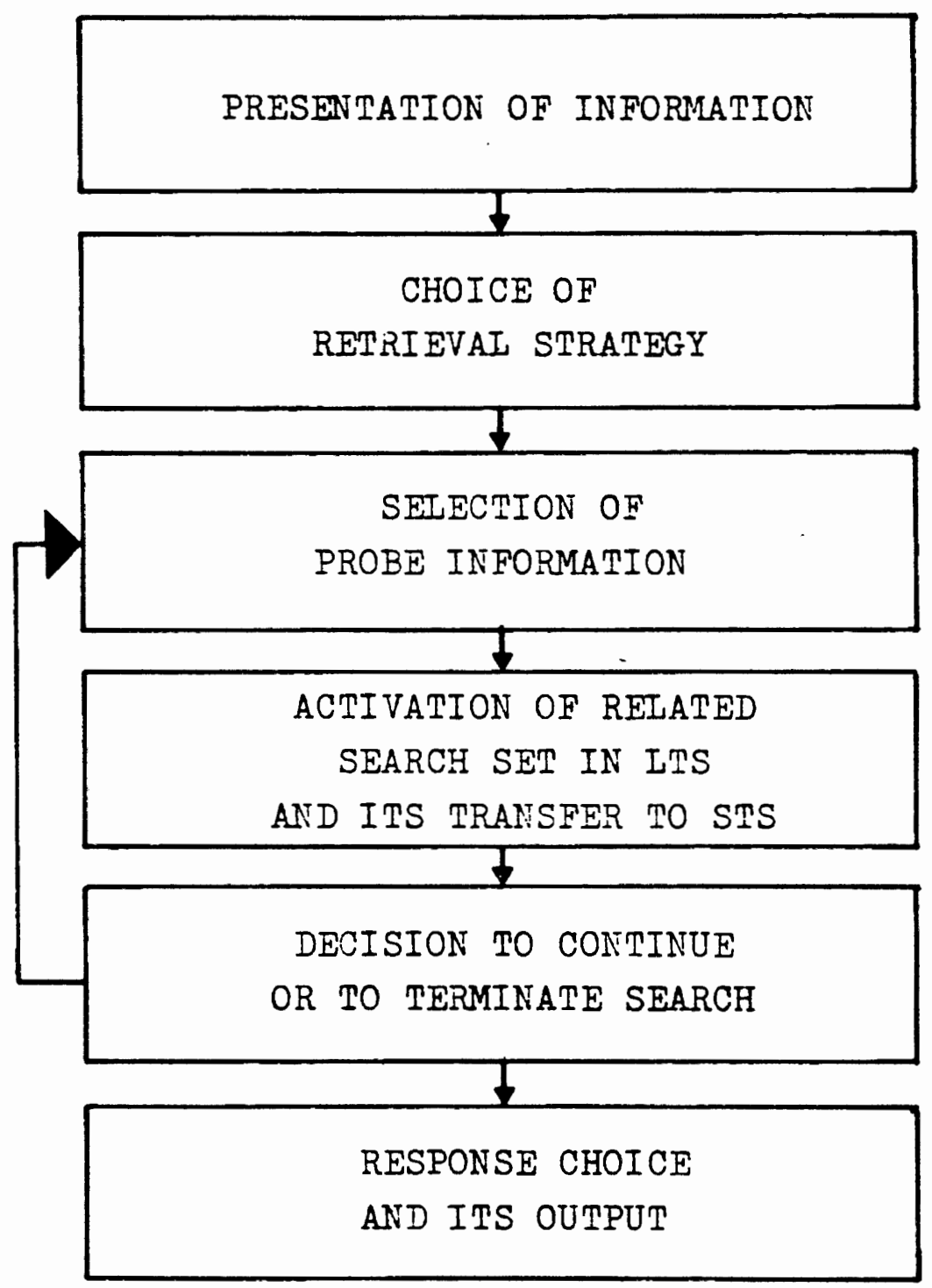

Figure 3. Retrieval model (Atkinson and Shiffrin, 1971). 
Shiffrin model somewhat and minimized the importance of the STM (see Figure 4). In Iversen's model, an immediate memory has been added. She proposed that the immediate memory has direct access to the long-term store, and that tasks involving uncomplicated registration and immediate retrieval may not involve the short-term memory at all. The short-term memory is only brought into action when the "quality, quantity, organization, or temporal characteristics" of the incoming information overload the direct route into permanent storage. Reportedly, Atkinson and Shiffrin later modified their model to include this "direct route" capacity (Schulter, 1975).

Iversen (1973) qualified the "direct route" concept when referring to human memory. During the memory process, humans activate a verbal coding mechanism. Verbal coding strategies play a central role in memory processing, even for information which is essentially nonverbal. The verbal coding mechanism is a "complex process" which demands the involvement of the short-term memory.

Because of the component of verbal coding in the memory process of humans, the Atkinson and Shiffrin (1971) model will be operationally utilized for the purposes of this review.

\section{Auditory Memory and Speech/Language Development}

Importance of Auditory STM

Atkinson and Shiffrin (1971) demonstrated the importance of the STM to the entire memory process. One type of STM in turn proves to be vital to the development of speech and language. This is the auditory short-term memory.

Audition is the basic means through which the individual maintains 


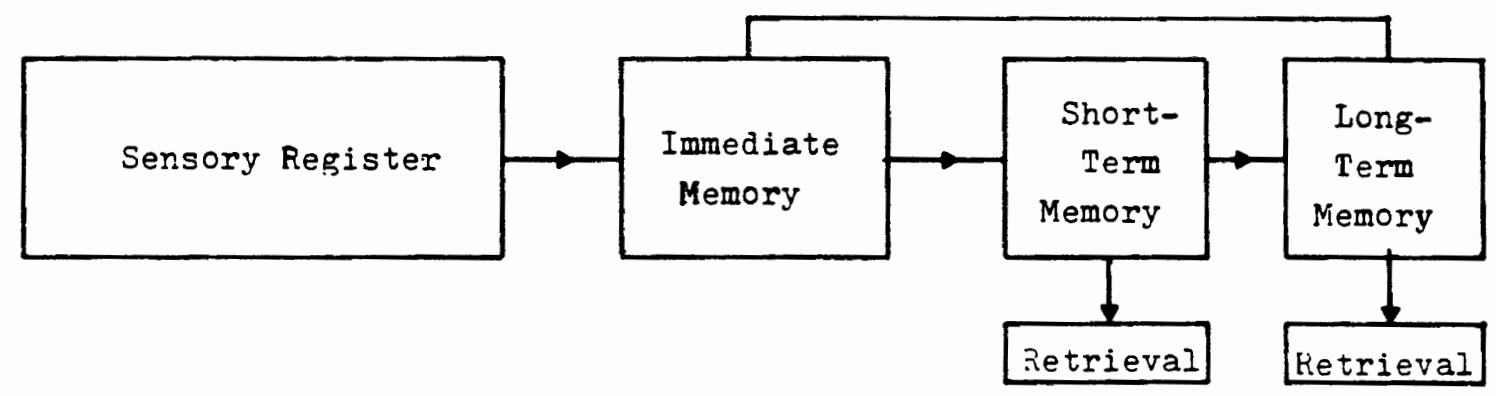

Figure 4. Model including immediate memory (Iversen, 1973). 
contact with his environment. The child's first meaningful associations with words are through the auditory mode (Johnson and Mykelbust, 1967; Elliott and Strawhorn, 1976). The child attends both to sound qualities and to the temporal distribution of sounds in a pattern. Although the child reacts perceptually to a pattern as a whole, he must be able to discriminate sequences of sounds to comprehend the message accurately, e.g., that "s" indicates plurality. As the child's auditory processing skills mature, the child develops the capacity to store auditory symbols and experiences (Zigmond and Cicci, 1968). Indeed every facet of speech and language development depends on memory (Johnson and Mykelbust, 1967; Zigmond and Cicci, 1968).

\section{Limits of the Auditory STM}

Al though the auditory STM is so important for speech and language development, it has definite limits. Miller (1956) stressed that the individual possesses a finite and rather small capacity for making unidimensional judgments, and that this capacity remains virtually invariant from one sensory mode to another. More variables may be added to the "display" to increase total capacity but this results in a decrease in the accuracy of determining a particular variable. This means that individuals make relatively crude judgments when called upon to process several things simultaneousiy.

Miller applied this idea of judgment memory limitation to speech and language development. In human speech there are eight to ten dimensions, or distinctive features, that differentiate one phoneme from another. It is undetermined whether this limit is imposed by the nature of the perceptual machinery (which includes auditory STM), or by the nature of the speech machinery that must produce sounds. Miller implied 
that the limitation lies in the STM.

Miller (1956) further indicated that since the memory span is limited by the number of "chunks" it can hold, one can increase the number of "bits" of information held by simply building larger and larger chunks, each containing more information. Miller referred to this process as re-coding. He indicated that the simplest way to recode is to group input events, apply a new name to the group, and then remember the new name rather than the original input events.

\section{Auditory STM and Speech Development}

As Miller (1956) suggested, the organism responds to the limitations of the auditory STM by deveroping strategies such as recoding and is thus able to learn speech and language. Eimas (1975) examined distinctive features in terms of STM and speech development. He found that when subjects made errors in repeating strings of sounds (an auditory STM task), errors proved to be a positive function of the number of distinctive features shared by the correct and error sounds. Elliott and Strawhorn (1976), in their studies on memory interference, concurred with the theory that the STM is highly sensitive to interference by similar cognitive activity. Eimas concluded his statement regarding distinctive features and STM by proposing that "with increasing maturity, the phonetic code, represented by distinctive features, becomes available for other functions such as the production of speech and short-term storage."

Pisoni (1973) suggested a specific way in which the auditory STM is utilized for speech development. He referred to the work of Fugisaki and Kawashima (1970) who indicated that the acoustic cues (formant transitions) that distinguish stop consonants are relatively short in duration. These cues therefore cannot be stored well in memory. Acoustic 
cues (formant frequencies) that distinguish vowels extend for the entire duration of the stimulus and are therefore more easily stored. Pisoni concluded that the discrimination of vowels from consonants is primarily due to the differential availability of the auditory STM for acoustic cues. Furthermore, auditory STM for the acoustic properties of vowels is better than auditory STM for the acoustic properties of consonants. These conclusions seem highly plausible since consonants are more frequently misarticulated than vowels.

\section{Auditory STM and Language Development}

As demonstrated above, the auditory STM is involved in the acquisition of speech sounds, but is it equally involved in the acquisition of language? Witkin (1971) noted that the sequential aspect of the auditory STM is necessary for the acquisition of language skills. She stressed that words and sentences are made up of series of sounds presented in a temporal order and this order is a major dimension of language.

Scholes (1976) examined the development of sentence comprehension in terms of auditory STM. He found that young children comprehend sentences as a function of the number of words that the sentence contains. The comprehension level depends on this very superficial characteristic which is strictly a STM span phonomemon. With maturity and experience in language, the individual acquires lexicon and syntax. In addition, the individual acquires information dealing with the sequential frequencies and probabilities of language. By the time the individual becomes an adult, comprehension is no longer based solely on the surface form of the material but on the degree to which the sequence of events is predictable.

Carrow and Mauldin (1973) and Smith (1970) concurred with Scholes' 
theory. Carrow and Mauldin found that the more "grammatical" a stimulus was, the more easily it was remembered by all age groups. The older the child, though, the better able the child was to make use of the increased structure of the stimulus. Carrow and Mauldin proposed that this developmental change may have been the result of the differences in language structure competence or in the age-related constraints on memory and processing.

Smith (1970) attributed the differential response of children in recalling specific linguistic input directly to a change in the memory and processing abilities. Smith saw this difference as a mechanical constraint rather than a grammatical or notional one. She indicated that repetition involves the auditory STM and that individuals can hold more material here when they can structure it, viz., Miller's recoding of "chunks." Smith suggested the possibility that in some circumstances, a mechanical constraint may keep a child from using his full linguistic capacities.

The auditory STM is involved in the discrimination of sounds, the combining of sounds into words, the combining of words into sentences, and development of syntax. Both the span and sequence aspects of the auditory STM are drawn upon. As demonstrated by the above-mentioned research, auditory STM is inextricably involved in speech and language development.

\section{Auditory STM and the Learning Disabled Child}

\section{Implications for the Learning Disabled Child}

If the auditory STM is indeed so important to speech and language development, what is the result if an individual's STM "malfunctions"? 
It is a common observation in the field of education that learning disabled (LD) children are often unable to recall or reproduce a sequence of numbers, letters, or non-meaningfur symbols (McCarthy and McCarthy, 1969). Zigmond (1969) discussed the limitations of LD children in regard to storage and retrieval by stating that many $L D$ children are limited in the amount of information they can store at one time. In addition to storage, an individual must have a mechanism for retrieval and reproduction of stored data. LD children are often unable to retrieve or remember information for spontaneous usage. According to the Atkinson and Shiffrin (1971) model of the memory process, such disabilities must result from limitations within the STM since this controls storage and retrieval processes. The speech and language development of the LD child is therefore interrupted because of a faulty STM.

\section{Diagnostic Implications}

Since LD children perform poorly on memory-related tasks, perhaps an assessment of auditory STM could prove to be an important diagnostic factor in identifying such children. Aten and Davis (1968) tested children with minimal cerebral dysfunction (MCD) and normal children on specific memory tasks. The authors attributed the poorer performance of MCD children directly to shorter perceptual spans and less accurate reproduction of sequential information. Monsees (1968) found a direct relationship between poor intelligibility of language expression (as often demonstrated by LD children) and problems of auditory temporal sequence processing. Schwalb (1969) indicated that LD children, as a result of an inability to sequence, demonstrate receptive as well as expressive language difficulty. These children also have difficulty in auditory discrimination and differentiation. As Mykelbust and Johnson 
(1962) concluded after studying LD children, "these memory deficiencies are of the utmost importance diagnostically and theraputically."

Are auditory STM subtests on widely administered, intelligence-type tests actually diagnostic of LD children?. Ackerman (1971) utilized the Wechsler Intelligence Scale for Children (WISC) to compare normal and LD children. She found that LD children performed lower than controls at a statistically reliable level on four subtests of the WISC. One of these four subtests was Digit Span (an auditory STM test). Ackerman concluded that the primary deficiency of LD children is an inability to "hold" several bits of information until the bits can be synthesized into a workable whole. This factor is most likely to be the one tapped by the Arithmetic and Digit Span subtests of the WISC.

Stark (1967) noted diagnostic significance in the Auditory-Vocal Sequencing subtest of the Illinois Test of Psycholinguistic Abilities (ITPA). Stark utilized a variety of memory tests in addition to the ITPA subtest. LD children performed significantly below age level on al1 tests in Stark's battery and performance on the Auditory-Vocal Sequencing subtest was more than two years below chronological age level. Stark concluded that these results supported the observation that LD children display particular deficits in temporal sequencing.

Though the above-mentioned authors found the auditory STM subtests on the WISC and the ITPA to be diagnostically useable in identifying LD children, other authors have criticised these subtests on the basis of low statistical reliability and validity, and lack of diagnostic significance. Senf and Freundl (1972) indicated that the reliability level of of the Digit Span subtest on the WISC was .50 to .60 for el ementary school children. This proved to be the lowest reliability score of all 
WISC subtests. Senf and Freundl disagreed with Ackerman (1971) by stating that because of the limited variability in scores on the Digit Span subtest, the likelihood of finding identifiable differences between LD and normal children was extremely small. Newcomer and Hammi11 (1976) took the Auditory Sequential Memory subtest of the ITPA to task. As mentioned above, Kirk, McCarthy, and Kirk (1968) attempted to make this subtest "more diagnostic" of LD children by changing the stimulus presentation to one digit per $\frac{1}{2}$ second rather than one per second (as utilized on the WISC). Newcomer and Hammill examined twenty-four correlational studies of ITPA subtests. They found that despite the stimulus presentation change, the Auditory Sequential Memory subtest did not demonstrate statistical predictive and diagnostic validity.

The controversy remains unsettled concerning the use of the STM subtests on the WISC and the ITPA. Various authors have developed tests that focused specifically on memory (Aten and Davis, 1968; Wepman and Morency, 1973) but none of these tests have gained widespread acceptance and usage. Because of varied and discrepant research results for STM tests, Burford (1976) developed the Auditory Memory Test Battery (AMTB). In the AMTB, Burford evaluated the aspects of span and sequence separately. She further utilized five different stimulus types in order to compare these types objectively. McCausland (1978) field-tested the AMTB with learning disabled and normal children. She found significant differences between groups for all stimulus types. With further research and standardization, the AMTB may gain diagnostic significnace and acceptance as a test which reliably identifies LD children through the parameter of auditory STM. 


\section{Summary}

The human memory process involves the short-term memory and the long-term memory. The STM controls both the storage and retrieval of information. The auditory STM holds specific significance for the development of speech and language. Through the two subskills of span and sequence, the auditory STM controls sound discrimination, word formation, and the development of syntax. When the STM fails to perform adequately, the individual experiences disabilities along the speech/language continuum. Such an individual is commonly labeled "learning disabled." Since STM deficits occur among LD children, an auditory STM assessment is useful in identifying such children so that remediation can take place. The AMTB was developed to act as such a diagnostic tool, but norms are lacking. The present study therefore sought to provide normative data for the AMTB. 


\section{CHAPTER III}

METHODS AND PROCEDURES

\section{Subjects}

Subjects for this study included 25 children at each grade level (2nd, 3rd, 4th) from the Scappoose, Oregon School District. Subjects were randomly selected from a group of children which met the following criteria:

1) Received permission from parent or guardian to participate in the study. (see Permission Form, Appendix A).

2) Received no remedial speech, language, or reading instruction, as reported by the parents. (see Permission Form, Appendix A).

3) Passed the speech and language screening administered by the school speech pathologist, as determined by consulting the speech pathologist.

4) Displayed no known physical handicap, as reported by the classroom teacher.

5) Passed the audiometric screening administered by this examiner by responding positively to two of three presentations at $25 \mathrm{~dB} \mathrm{HL}$ for each of the tones $500 \mathrm{~Hz}$, $1000 \mathrm{~Hz}, 2000 \mathrm{~Hz}$, and $4000 \mathrm{~Hz}$ bilaterally.

Subjects were selected with no preference to sex. The sample was comprised of 13 males and 12 females from the 2 nd grade (age range 7-6 
through 8-7), 11 males and 14 females from the 3rd grade (age range 8-7 through 9-7), and 8 males and 17 females from the 4 th grade (age range 9-7 through 10-4). The economic level of the area from which the subjects were drawn was determined to be lower-to-middle income since this area receives Title I funds, i.e., funds awarded to schools with a large percentage of students from low income families.

\section{Instrumentation}

The Auditory Memory Test Battery (AMTB) (Burford, 1976) (see Appendix $B$ ) consists of the following subtests:

1) Digit Sequencing

2) Related Word Sequencing

3) Unrelated Word Sequencing

4) Sentence Sequencing

5) Nonsense Word Sequencing

Each subtest of the AMTB was comprised of the following: 1) two sample items, each two monosyllables in length, at the beginning of each subtest and 2) fourteen test items ranging in length from two to eight monosyllables. Serial word items were presented at the rate of two per second with falling vocal inflection at the end of each sequence. This falling inflection acted as a cue to the subject that the stimulus signal had terminated. Sentence items were presented at the rate of two words per second using normal inflection. A ten second pause followed each item, giving the subject time to respond. Each item was comprised of two trial and two response periods. All subtests were prerecorded on cassette tapes using the voice of Burford.

The five subtests of the AMTB were duplicated from reel-to-reel 
tape onto five individual cassette tapes. This procedure was done using Maxcel1 C-30 cassette tapes. For randomization of administration purposes, each cassette was given a number (1-5).

Audiometric screening was administered with a Beltone portable audiometer model \#10c.

A Pioneer centrex cassette tape recorder, model \#KD-12, was utilized for AMTB administration.

\section{Test Administration}

To gain rapport, the examiner engaged in casual conversation with the child before beginning testing. The hearing screening and AMTB were administered in a consistently quiet room in the subject's school. During testing, the subject sat across a small table from the examiner. The tape recorder, tapes, and response forms were placed to the right of the examiner. Response forms as well as the lists of subjects were placed out of the subject's view.

Prior to test administration, the examiner noted the subject's name and assigned the subject a subtest randomizing number (see Subtest Randomizing List, Appendix C) on a response form (see Response Form, Appendix B).

The examiner gave the following verbal instructions to each subject:

I am going to play five tapes for you. On each tape there will be a lady saying some words. Please listen very carefulty to what the lady says. Whenever she stops you say the same thing she just did. The lady will say the words two times. She will say them, then you say them; she will say the words again, then you say them again. Some of the things she will say will be harder to remember than others, and some won't make sense. Just listen carefully and do the best you can to say exactly what she says.

The examiner proceeded to play the two trial items on the first 
tape. If the subject failed to respond to at least the second trial of the first sample item, the tape was stopped, the subject was reinstructed, and the second sample item was played. The tape was not turned off again unless the subject failed two consecutive test items on both trials. The subtest was then discontinued. Following the administration of each subtest, the examiner gave positive reinforcement such as "you're doing a good job" and the instructions, "listen carefully; the next tape will be different from this last one." These procedures were followed for all five subtests. An additional instruction was given prior to the nonsense word subtest: "These won't make sense."

Administration of the hearing screening and the AMTB was completed in one session. The average session duration, was 30 minutes.

\section{Scoring Procedures}

During each subtest, the examiner recorded all responses and utilized the following procedures:

1) A totally correct response on either trial was marked by placing a check $(\mathcal{V})$ beside the corresponding item on the response form (see Appendix B).

2) Criteria for correctness were:

a) A11 words in an item were named and, further, words were named in correct serial order.

b) A11 words in responses to digits, related words, and sentence items had to match the stimulus words exactiy.

c) A11 words in responses to unrelated word and nonsense word items could deviate by one distinctive feature of one consonant per word (Drexler, 1974) (see Appendix D). An example of a deviation of one distinctive feature is the response "card" to the stimulus "cart." 
3) An incorrect response on either trial of an item was recorded by transcribing the error directly below the stimulus on the response form. Digit responses were recorded as digits, word responses as words, and nonsense word responses as phonetic symbols using the International Phonetic Alphabet. Unintelligible repsonses were recorded as such on the response form.

4) If the response to the first trial on any item was correct, the second trial on that item was administered but not scored.

Following administration of the AMTB, items were scored for both span (all words in an item recalled) and sequence (all words in correct serial order). The scoring procedure was as follows:

1) Responses completely correct on the first trial received two points each for span and sequence.

2) Responses completely correct on the second trial received one point each for span and sequence.

3) Responses including all words in an item, but not in correct serial order, on the first trial received two points for span and none for sequence.

4) Responses including a 11 words in an item, but not in correct serial order, on the second trial received one point for span and none for sequence.

For any responses to two trials of an item, the subject was credited with the greater number of points received for span. If, for example, the subject recalled all of the words in an item on the first trial, but erred in the serial order, then went on to respond correctly on the second trial, the subject received two points for span and one point for 
sequence on that item.

A total span score was determined for each of the five subtests by adding span scores within each subtest. This procedure was also utilized to determine the total sequence score. Therefore, each subject obtained 10 total scores: a span score and a sequence score for each of five subtests, with a possible twenty-eight points for each subtest for span and sequence.

\section{Data Analysis}

Data was analyzed using the arithmetic average formula to determine means $(\bar{x})$, and the square root of the variance formula to determine the standard deviations (SD) for memory span and sequence for each of three grade levels.

Mean $=\bar{x}=\frac{\sum_{i=1}^{N} x_{i}}{N}$

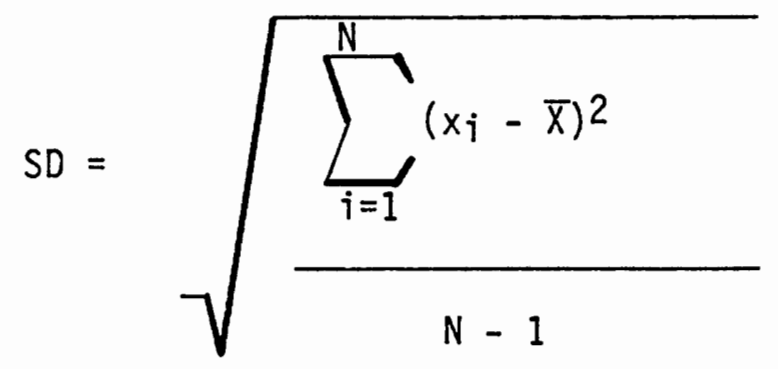

Data was further compared using $\underline{t}$-tests for dependent means and independent means. The following are the formulas for these operations.

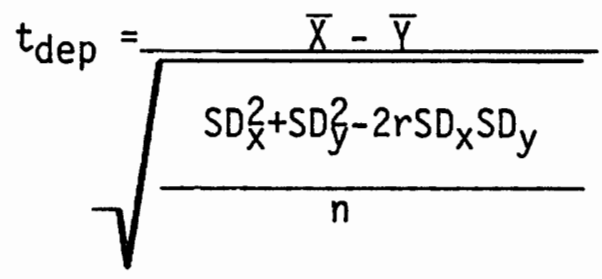


$t_{\text {ind }}=\frac{\bar{x}-\bar{y}}{\sqrt{\left[\frac{\left(n_{x}-1\right) S D_{x}^{2}+\left(n_{y}-1\right) s D_{y}^{2}}{n_{x}+n_{y}-2}\right]\left[\frac{1}{n_{x}}+\frac{1}{n_{y}}\right]}}$ 
CHAPTER IV

\section{RESULTS AND DISCUSSION}

\section{Results}

This study sought to provide normative data for the Auditory Memory Test Battery (AMTB). In addition, three corollary questions were to be answered.

The main experimental question was: what are the means and standard deviations for each of three grade levels (2nd, $3 r d, 4$ th) on the AMTB? Results determined by the arithmetic average formula and the square root of the variance formula are illustrated in Table I. Subtest results for 2nd and $3 r d$ graders proved fairly equat. The mean performance of 2 nd graders actually exceeded that of the 3rd graders on the following subtests: Related Words-Sequence, Unrelated Words-Sequence, SentencesSequence, Digits-Span, Related Words-Span, Unrelated Words-Span, and Sentences-Span. However, no statistically significant differences between these two grade levels were demonstrated. Statistical differences between age levels are noted in Table II. The 4th graders did differentiate themselves from the 2nd and 3rd graders on the auditory STM parameter. 4 th graders performed better than 2 nd graders at a statistically significant level on three subtests: Related Words-Sequence, Nonsense Words-Sequence, and Nonsense Words-Span. 4th graders out-performed 3rd graders at a statistically significant level on four subtests: Related Words-Sequence, Unrelated Words-Sequence, Related Words-Span, and Unrelated 


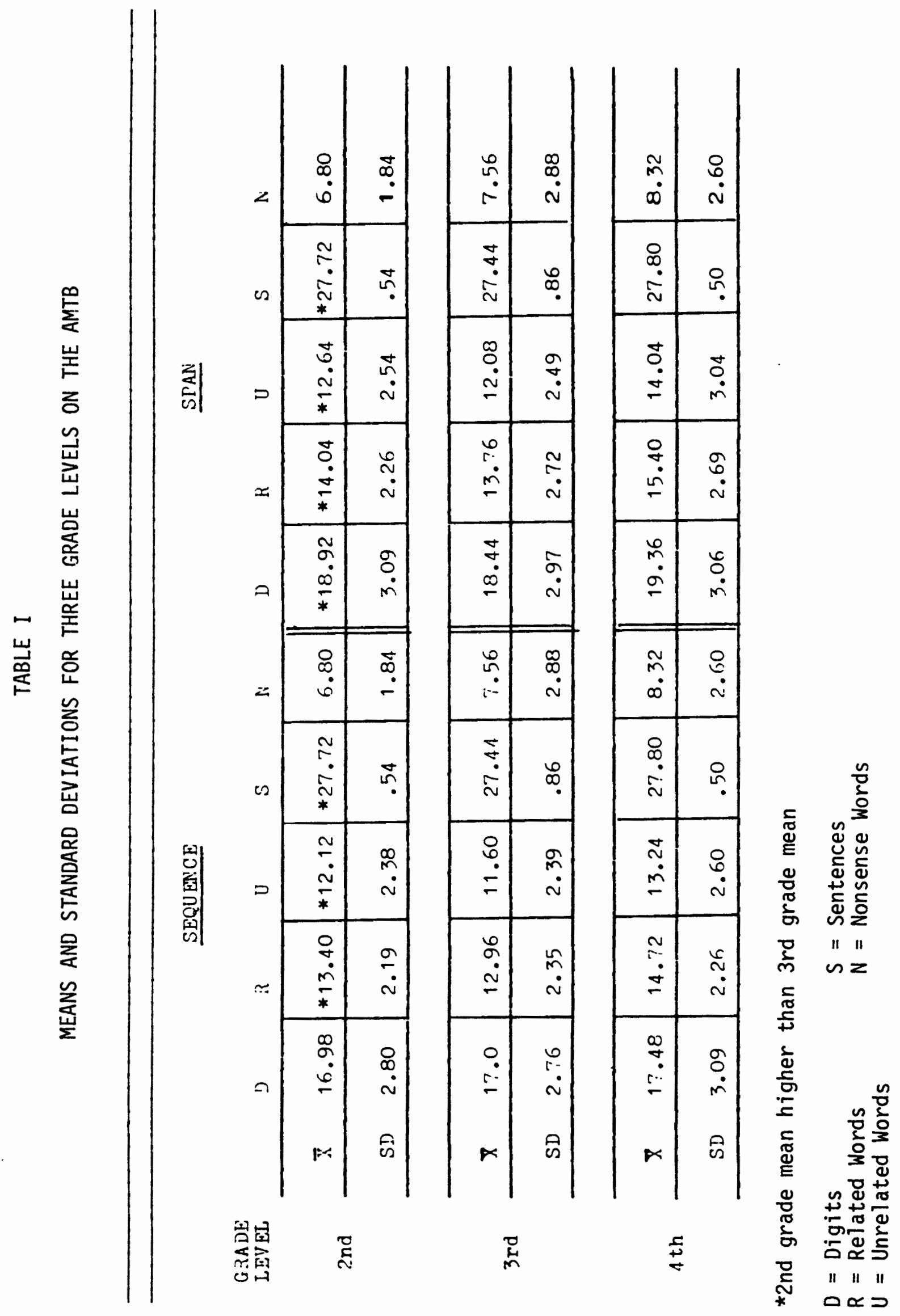




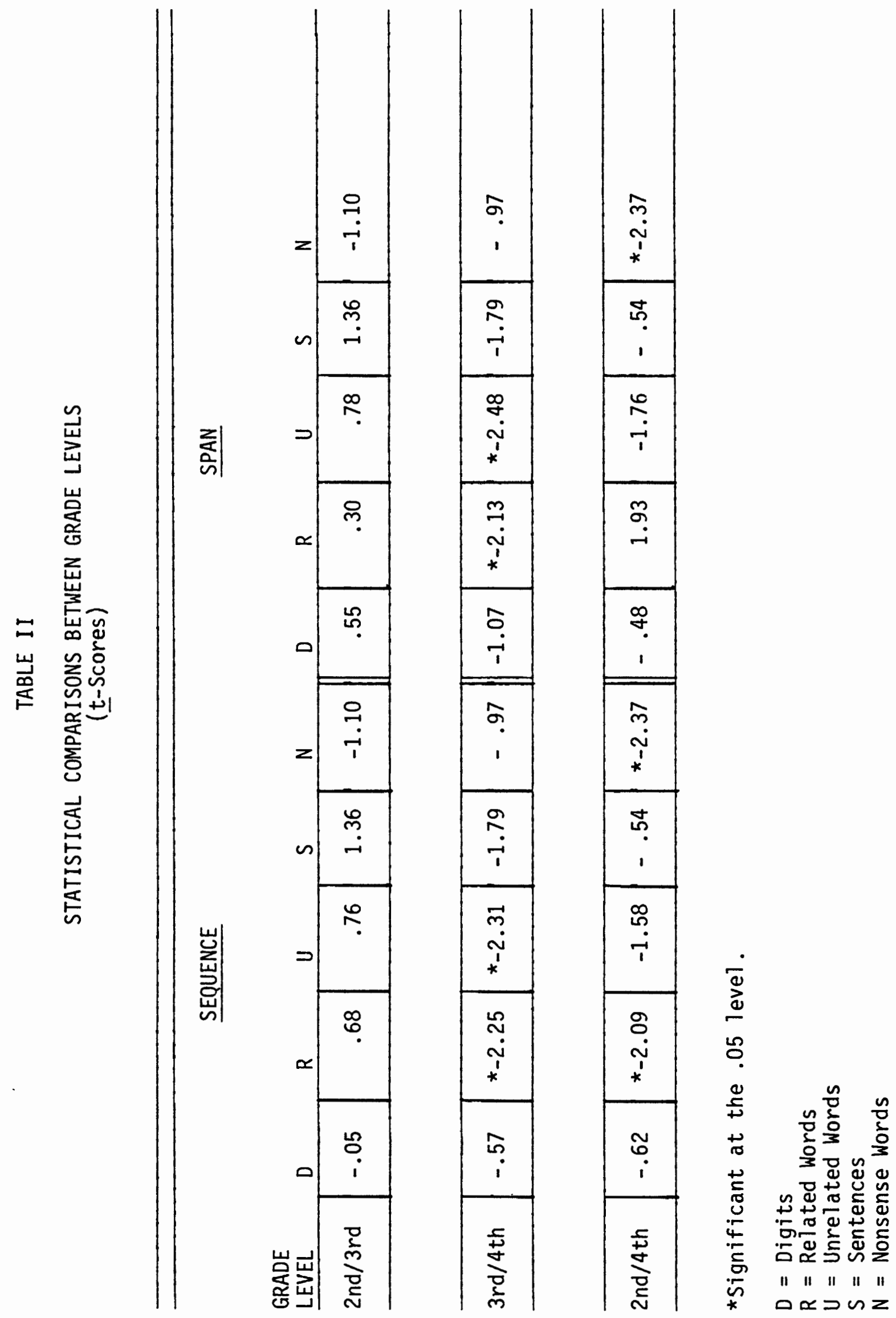


Words-Span.

The first corollary question was: is there a statistically significant difference between scores for span and scores for sequence on the AMTB? Results are noted in Table III. For these experimental subjects at all grade levels, scores for span were significantly greater than scores for sequence on the Digit, Related Words, and Unrelated Words subtests. Span and sequence scores for the Sentence and Nonsense Words subtests were identical, so no variance could be examined.

The second corollary question asked: how do test results drawn from a low income area compare with results drawn from an upper-middle income area? Experimental subjects from this study comprised the low income area group. Subjects utilized by Burford (1976) comprised the upper-middle income area group. Results are illustrated in Table IV. Because the raw data for Burford's study was unavailable, a statistical $\underline{t}$-test to examine differences between groups could not be run. However, upon visual inspection, no significant differences were evident. Though the higher income group's means were slightly larger on $8 / 10$ subtests, the greatest difference between means was .56 on the Digit-Span subtest with differences between group means on $5 / 10$ subtests being measured in hundredth's of a point.

The third corollary question asked: how do an individual's test scores compare with teacher judgments of the child's intelligence grouping (low, middle, high)? Results of this experimental question are illustrated in Tables $V$ through VII. Tables note means, standard deviations, and $\underline{t}$-scores for the various groups. Because only two children out of the entire experimental sample were rated "low," only the "high" and "middle" groups were compared experimentally. As the 


\section{TABLE III}

STATISTICAL COMPARISONS BETWEEN

SPAN AND SEQUENCE SCORES

(t-Scores)

\begin{tabular}{l|l|l|l|l|l}
$\begin{array}{l}\text { GRADE } \\
\text { LEVEL }\end{array}$ & D & \multicolumn{2}{c}{ R } & U & S \\
\hline 2nd & -7.89 & -3.36 & -3.16 & - & N \\
\hline
\end{tabular}

\begin{tabular}{l|l|l|l|l|l}
\hline 3rd & -6.03 & -4.17 & -2.49 & - & - \\
\hline
\end{tabular}

\begin{tabular}{l|l|l|l|l|l}
\hline 4 th & -6.89 & -3.44 & -3.46 & - & - \\
\hline
\end{tabular}

All listed measures are significant at the .05 level.

$$
\begin{aligned}
& D=\text { Digits } \\
& R=\text { Related Words } \\
& U=\text { Unrelated Words } \\
& S=\text { Sentences } \\
& N=\text { Nonsense Words }
\end{aligned}
$$




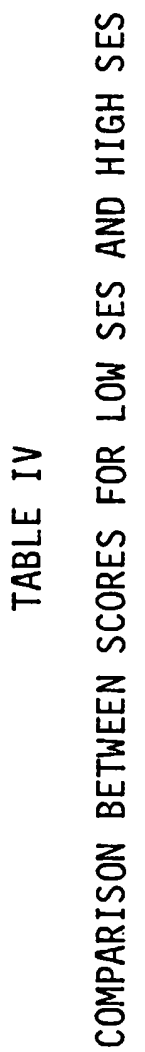
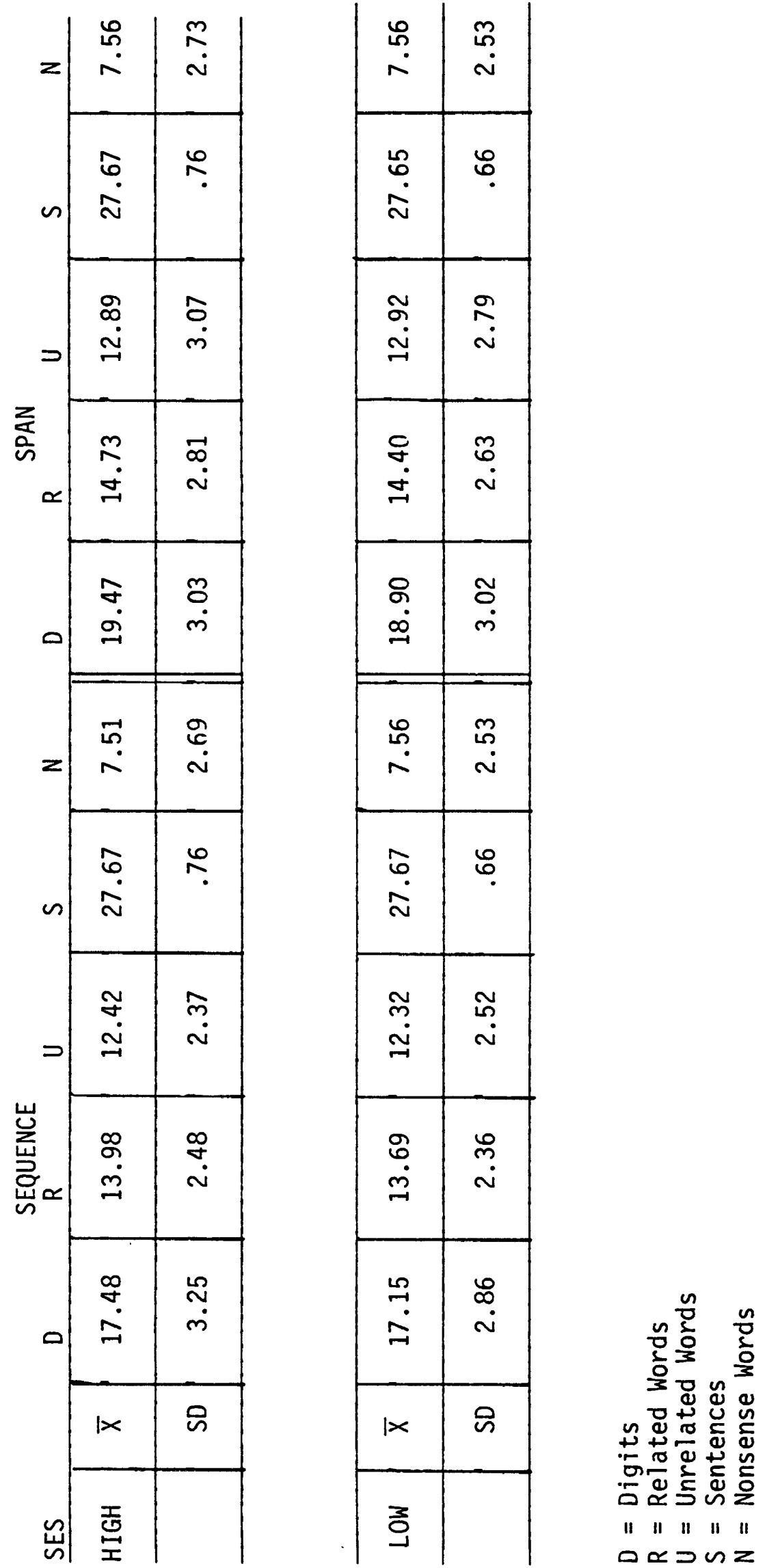
TABLE $V$

COMPARISON BETWEEN SUBTEST SCORES AND INTELLIGENCE GROUPS

(SECOND GRADE)

\begin{tabular}{|c|c|c|c|c|c|}
\hline $\begin{array}{l}\text { SEQUENCE } \\
\text { MEASURES }\end{array}$ & $\begin{array}{l}\text { INTELLIGENCE } \\
\text { GROUP }\end{array}$ & $\bar{x}$ & SD & $N$ & $\underline{t}$ \\
\hline DIGITS & $\begin{array}{l}\text { HIGH } \\
\text { MIDDLE }\end{array}$ & $\begin{array}{l}17.66 \\
16.75\end{array}$ & $\begin{array}{l}3.25 \\
1.81\end{array}$ & $\begin{array}{l}12 \\
12\end{array}$ & -.85 \\
\hline $\begin{array}{l}\text { RELATED } \\
\text { WORDS }\end{array}$ & $\begin{array}{l}\text { HIGH } \\
\text { MIDDLE }\end{array}$ & $\begin{array}{l}13.25 \\
13.08\end{array}$ & $\begin{array}{l}2.26 \\
2.15\end{array}$ & $\begin{array}{l}12 \\
12\end{array}$ & -.38 \\
\hline $\begin{array}{l}\text { UNRELATED } \\
\text { WORDS }\end{array}$ & $\begin{array}{l}\text { HIGH } \\
\text { MIDDLE }\end{array}$ & $\begin{array}{l}12.75 \\
10.83\end{array}$ & $\begin{array}{l}1.95 \\
2.16\end{array}$ & $\begin{array}{l}12 \\
12\end{array}$ & $\star 2.27$ \\
\hline SENTENCES & $\begin{array}{l}\text { HIGH } \\
\text { MIDDLE }\end{array}$ & $\begin{array}{r}27.41 \\
\# 27.50\end{array}$ & $\begin{array}{l}.99 \\
.79\end{array}$ & $\begin{array}{l}12 \\
12\end{array}$ & .22 \\
\hline $\begin{array}{l}\text { NONSENSE } \\
\text { WORDS }\end{array}$ & $\begin{array}{l}\text { HIGH } \\
\text { MIDDLE }\end{array}$ & $\begin{array}{r}7.75 \\
\# 7.83\end{array}$ & $\begin{array}{l}3.25 \\
2.16\end{array}$ & $\begin{array}{l}12 \\
12\end{array}$ & .07 \\
\hline $\begin{array}{l}\text { SPAN } \\
\text { MEASURES }\end{array}$ & $\begin{array}{l}\text { INTELLIGENCE } \\
\text { GROUP }\end{array}$ & $\bar{x}$ & SD & $\mathrm{N}$ & $\underline{t}$ \\
\hline DIGITS & $\begin{array}{l}\text { HIGH } \\
\text { MIDDLE }\end{array}$ & $\begin{array}{l}19.50 \\
17.91\end{array}$ & $\begin{array}{l}3.39 \\
1.56\end{array}$ & $\begin{array}{l}12 \\
12\end{array}$ & -1.46 \\
\hline $\begin{array}{l}\text { RELATED } \\
\text { WORDS }\end{array}$ & $\begin{array}{l}\text { HIGH } \\
\text { MIDDLE }\end{array}$ & $\begin{array}{l}14.33 \\
13.45\end{array}$ & $\begin{array}{l}2.96 \\
2.50\end{array}$ & $\begin{array}{l}12 \\
12\end{array}$ & -.75 \\
\hline $\begin{array}{l}\text { UNRELATED } \\
\text { WORDS }\end{array}$ & $\begin{array}{l}\text { HIGH } \\
\text { MIDDLE }\end{array}$ & $\begin{array}{l}13.41 \\
11.16\end{array}$ & $\begin{array}{l}1.83 \\
2.15\end{array}$ & $\begin{array}{l}12 \\
12\end{array}$ & $\star 2.82$ \\
\hline SENTENCES & $\begin{array}{l}\text { HIGH } \\
\text { MIDDLE }\end{array}$ & $\begin{array}{r}27.41 \\
\# 27.50\end{array}$ & $\begin{array}{l}.79 \\
.79\end{array}$ & $\begin{array}{l}12 \\
12\end{array}$ & .27 \\
\hline $\begin{array}{l}\text { NONSENSE } \\
\text { WORDS }\end{array}$ & $\begin{array}{l}\text { HIGH } \\
\text { MIDDLE }\end{array}$ & $\begin{array}{r}7.75 \\
\# 7.83\end{array}$ & $\begin{array}{l}2.16 \\
2.16\end{array}$ & $\begin{array}{l}12 \\
12\end{array}$ & .07 \\
\hline
\end{tabular}

\# Mean for Middle group higher than mean for High group.

* Significant at the .05 level. 


\section{TABLE VI}

COMPARISON BETWEEN SUBTEST SCORES AND INTELLIGENCE GROUPS

(THIRD GRADE)

\begin{tabular}{|c|c|c|c|c|c|}
\hline $\begin{array}{l}\text { SEQUENCE } \\
\text { MEASURES }\end{array}$ & $\begin{array}{l}\text { INTELLIGENCE } \\
\text { GROUP }\end{array}$ & $\bar{x}$ & SD & $N$ & $\underline{t}$ \\
\hline DIGITS & $\begin{array}{l}\text { HIGH } \\
\text { MIDDLE }\end{array}$ & $\begin{array}{l}17.66 \\
16.75\end{array}$ & $\begin{array}{l}3.25 \\
1.81\end{array}$ & $\begin{array}{l}12 \\
12\end{array}$ & -.85 \\
\hline $\begin{array}{l}\text { RELATED } \\
\text { WORDS }\end{array}$ & $\begin{array}{l}\text { HIGH } \\
\text { MIDDLE }\end{array}$ & $\begin{array}{l}13.25 \\
13.08\end{array}$ & $\begin{array}{l}2.26 \\
2.15\end{array}$ & $\begin{array}{l}12 \\
12\end{array}$ & -.38 \\
\hline $\begin{array}{l}\text { UNRELATED } \\
\text { WORDS }\end{array}$ & $\begin{array}{l}\text { HIGH } \\
\text { MIDDLE }\end{array}$ & $\begin{array}{l}12.75 \\
10.83\end{array}$ & $\begin{array}{l}1.95 \\
2.16\end{array}$ & $\begin{array}{l}12 \\
12\end{array}$ & $\star 2.27$ \\
\hline SENTENCES & $\begin{array}{l}\text { HIGH } \\
\text { MIDDLE }\end{array}$ & $\begin{array}{r}27.41 \\
\# 27.50\end{array}$ & $\begin{array}{l}.99 \\
.79\end{array}$ & $\begin{array}{l}12 \\
12\end{array}$ & .22 \\
\hline $\begin{array}{l}\text { NONSENSE } \\
\text { WORDS }\end{array}$ & $\begin{array}{l}\text { HIGH } \\
\text { MIDDLE }\end{array}$ & $\begin{array}{r}7.75 \\
\# 7.83\end{array}$ & $\begin{array}{l}3.25 \\
2.16\end{array}$ & $\begin{array}{l}12 \\
12\end{array}$ & .07 \\
\hline $\begin{array}{l}\text { SPAN } \\
\text { MEASURES }\end{array}$ & $\begin{array}{l}\text { INTELLIGENCE } \\
\text { GROUPS }\end{array}$ & $\bar{x}$ & SD & $N$ & $\underline{t}$ \\
\hline DIGITS & $\begin{array}{l}\text { HIGH } \\
\text { MIDDLE }\end{array}$ & $\begin{array}{l}19.50 \\
17.91\end{array}$ & $\begin{array}{l}3.39 \\
1.56\end{array}$ & $\begin{array}{l}12 \\
12\end{array}$ & -1.46 \\
\hline $\begin{array}{l}\text { RELATED } \\
\text { WORDS }\end{array}$ & $\begin{array}{l}\text { HIGH } \\
\text { MIDDLE }\end{array}$ & $\begin{array}{l}14.33 \\
13.45\end{array}$ & $\begin{array}{l}2.96 \\
2.50\end{array}$ & $\begin{array}{l}12 \\
12\end{array}$ & -.75 \\
\hline $\begin{array}{l}\text { UNRELATED } \\
\text { WORDS }\end{array}$ & $\begin{array}{l}\text { HIGH } \\
\text { MIDDLE }\end{array}$ & $\begin{array}{l}13.41 \\
11.16\end{array}$ & $\begin{array}{l}1.83 \\
2.15\end{array}$ & $\begin{array}{l}12 \\
12\end{array}$ & $\star 2.82$ \\
\hline SENTENCES & $\begin{array}{l}\text { HIGH } \\
\text { MIDDLE }\end{array}$ & $\begin{array}{r}27.41 \\
\# 27.50\end{array}$ & $\begin{array}{l}.79 \\
.79\end{array}$ & $\begin{array}{l}12 \\
12\end{array}$ & .27 \\
\hline $\begin{array}{l}\text { NONSENSE } \\
\text { WORDS }\end{array}$ & $\begin{array}{l}\text { HIGH } \\
\text { MIDDLE }\end{array}$ & $\begin{array}{r}7.75 \\
\# 7.83\end{array}$ & $\begin{array}{l}2.16 \\
2.16\end{array}$ & $\begin{array}{l}12 \\
12\end{array}$ & .07 \\
\hline
\end{tabular}

\# Mean for Middle group higher than mean for High group.

* Significant at the .05 level. 


\section{TABLE VII}

COMPARISON BETWEEN SUBTEST SCORES AND INTELLIGENCE GROUPS

(FOURTH GRADE)

\begin{tabular}{|c|c|c|c|c|c|}
\hline $\begin{array}{l}\text { SEQUENCE } \\
\text { MEASURES }\end{array}$ & $\begin{array}{l}\text { INTELLIGENCE } \\
\text { GROUP }\end{array}$ & $\bar{x}$ & $S D$ & $N$ & $\underline{t}$ \\
\hline DIGITS & $\begin{array}{l}\text { HIGH } \\
\text { MIDDLE }\end{array}$ & $\begin{array}{l}19.00 \\
16.50\end{array}$ & $\begin{array}{l}3.36 \\
2.53\end{array}$ & $\begin{array}{l}10 \\
15\end{array}$ & $\star 2.14$ \\
\hline $\begin{array}{l}\text { RELATED } \\
\text { WORDS }\end{array}$ & $\begin{array}{l}\text { HIGH } \\
\text { MIDDLE }\end{array}$ & $\begin{array}{l}16.30 \\
13.66\end{array}$ & $\begin{array}{l}2.40 \\
1.44\end{array}$ & $\begin{array}{l}10 \\
15\end{array}$ & $\star-3.42$ \\
\hline $\begin{array}{l}\text { UNRELATED } \\
\text { WORDS }\end{array}$ & $\begin{array}{l}\text { HIGH } \\
\text { MIDDLE }\end{array}$ & $\begin{array}{l}14.27 \\
12.60\end{array}$ & $\begin{array}{l}3.34 \\
1.59\end{array}$ & $\begin{array}{l}10 \\
15\end{array}$ & -1.54 \\
\hline SENTENCES & $\begin{array}{l}\text { HIGH } \\
\text { MIDDLE }\end{array}$ & $\begin{array}{l}28.0 \\
27.66\end{array}$ & .61 & $\begin{array}{l}10 \\
15\end{array}$ & -1.69 \\
\hline $\begin{array}{l}\text { NONSENSE } \\
\text { WORDS }\end{array}$ & $\begin{array}{l}\text { HIGH } \\
\text { MIDDLE }\end{array}$ & $\begin{array}{l}9.3 \\
7.66\end{array}$ & $\begin{array}{l}2.52 \\
1.58\end{array}$ & $\begin{array}{l}10 \\
15\end{array}$ & -1.36 \\
\hline $\begin{array}{l}\text { SPAN } \\
\text { MEASURES }\end{array}$ & $\begin{array}{l}\text { INTELLIGENCE } \\
\text { GROUP }\end{array}$ & $\bar{x}$ & SD & $N$ & $\underline{t}$ \\
\hline DIGITS & $\begin{array}{l}\text { HIGH } \\
\text { MIDDLE }\end{array}$ & $\begin{array}{l}20.7 \\
18.46\end{array}$ & $\begin{array}{l}3.43 \\
2.53\end{array}$ & $\begin{array}{l}10 \\
15\end{array}$ & -1.87 \\
\hline $\begin{array}{l}\text { RELATED } \\
\text { WORDS }\end{array}$ & $\begin{array}{l}\text { HIGH } \\
\text { MIDDLE }\end{array}$ & $\begin{array}{l}17.0 \\
14.33\end{array}$ & $\begin{array}{l}2.98 \\
1.91\end{array}$ & $\begin{array}{l}10 \\
15\end{array}$ & $*_{-}-2.73$ \\
\hline $\begin{array}{l}\text { UNRELATED } \\
\text { WORDS }\end{array}$ & $\begin{array}{l}\text { HIGH } \\
\text { MIDDLE }\end{array}$ & $\begin{array}{l}15.0 \\
13.4\end{array}$ & $\begin{array}{l}3.91 \\
2.22\end{array}$ & $\begin{array}{l}10 \\
15\end{array}$ & -1.30 \\
\hline SENTENCES & $\begin{array}{l}\text { HIGH } \\
\text { MIDDLE }\end{array}$ & $\begin{array}{l}28.0 \\
27.66\end{array}$ &.$\overline{-}$ & $\begin{array}{l}10 \\
15\end{array}$ & -1.69 \\
\hline $\begin{array}{l}\text { NONSENSE } \\
\text { WORDS }\end{array}$ & $\begin{array}{l}\text { HIGH } \\
\text { MIDDLE }\end{array}$ & $\begin{array}{l}9.3 \\
7.66\end{array}$ & $\begin{array}{l}2.52 \\
1.58\end{array}$ & $\begin{array}{l}10 \\
15\end{array}$ & -1.36 \\
\hline
\end{tabular}

\#Mean for Middle group higher than mean for High group.

*Significant at the .05 level. 
tables illustrate, the mean scores for the "high" groups at each grade level were higher than the mean scores for the middle groups. The few exceptions are noted in the tables. The tables also illustrate instances in which the difference between groups was significant. For the 2nd graders, no significant differences were found. For the 3rd graders, significant differences were noted for the Unrelated Words-Sequence subtest and the Unrelated Words-Span subtest. For the 4th graders, significant differences existed for the Digits-Sequence, Related Words-Sequence, and Related Words-Span subtests.

\section{Discussion}

The results of this study reveal certain aspects of the auditory STM. The experimental expectation was that AMTB test results would demonstrate a "stair-step" pattern, i.e., 2nd graders would exhibit the lowest scores and the 4 th graders would exhibit the highest. This expectation was not strictiy bourne out. As noted previously, the performance of 2 nd and 3 rd graders proved fairly equal. The data suggests that a developmental change, as outlined by Carrow and Mauldin (1973) and Smith (1970), had not taken place between these two grade levels. However, the 4 th graders did differentiate themselves from the 2nd and 3rd graders in terms of auditory STM. The data therefore suggests the auditory STM follows a developmental growth pattern, but plateaus exist along the developmental ladder.

The comparison between span and sequence scores lent partial support to the work of Zigmond (1969). Zigmond noted differences between scores for span and scores for sequence among both normal children and learning disabled children. In this study, scores for span were significantly 
greater for Digits, Related Words, and Unrelated Words. This information was in opposition to the notion of Turiads, Wepman, and Morency (1972) who stated that such a differentiation did not exist for normal children. These findings did not concur with those of Burford (1976) who utilized the AMTB with normal children. Burford concluded that the only subtest in which normals scored significantly better on span than sequence was the Digit subtest. The larger sample size of the present study may have allowed for greater variability between span and sequence scores. Judging from the results of this study, it would appear that normal children tend to produce a better span score than sequence score. Data from this study was compared with that of Burford's (1976) study on the parameter of socio-economic status (SES). Within the samples studied, children of a low SES scored almost identically to those of a high SES on the AMTB. Using SES as an environmental gauge, findings suggest that auditory STM could be a "pure" capability within the individual which is relatively unaffected by the environment.

Assuming teachers' ratings of a child's intelligence level are indicative of actual functioning, the following results were noted. Children rated as being in the "high" intelligence group tended to score better than those rated in the "middle" intelligence group. These findings offer support to the postulation of Piaget and Inhelder (1973) that memory and intelligence are inextricably joined within the individual.

\section{Discussion of Results for LD Children}

For the sake of comparison, two 2 nd graders who were labelled as learning disabled were tested with the AMTB. The norms for these two children are listed in Table VIII and are compared with 2nd grade norms. The "LD norm" is well below the 2nd grade norm for all subtests except 

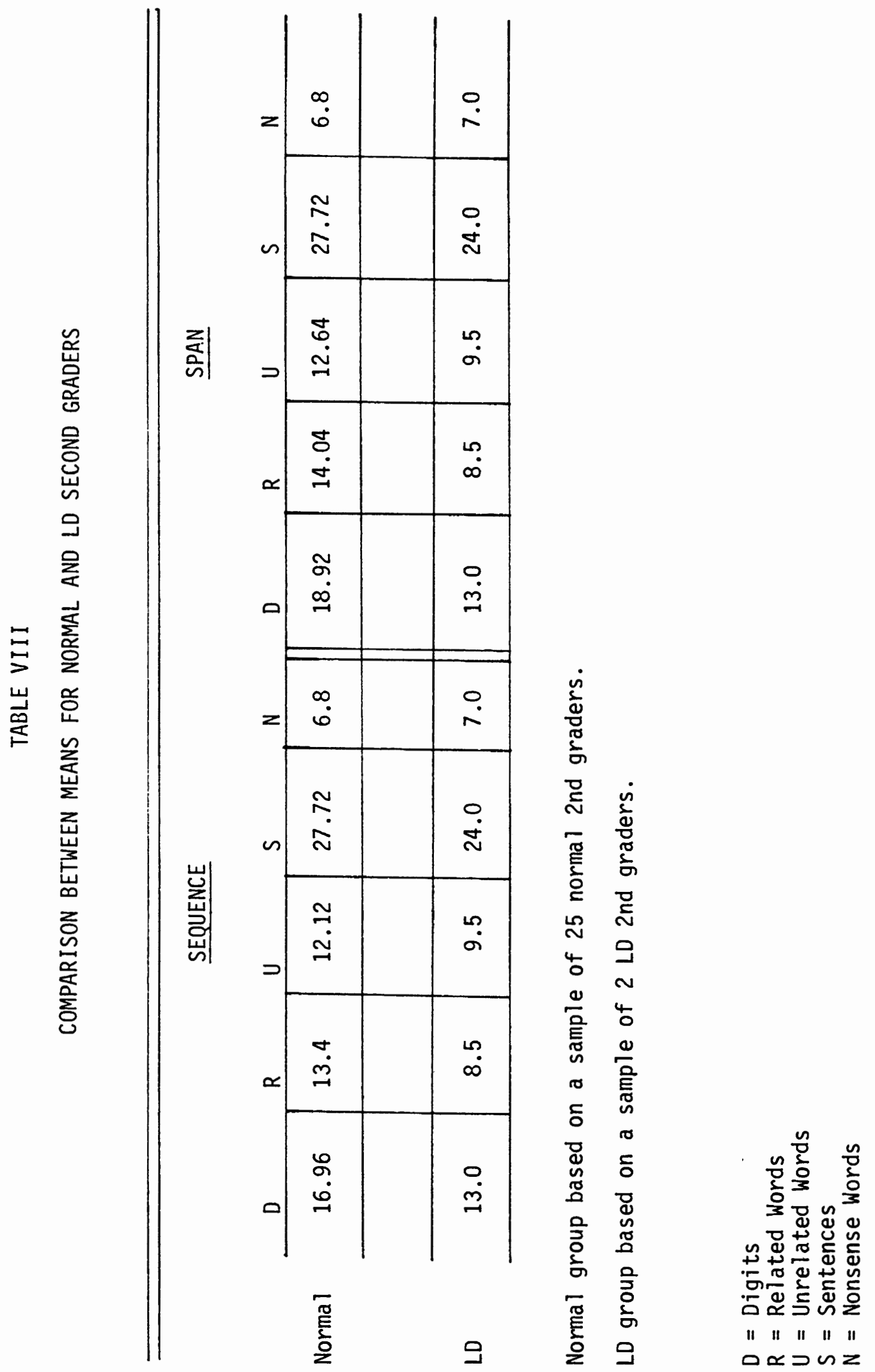
Nonsense Words. This finding generally concurs with that of McCausland (1978) who found LD children to score worse than normal children on all subtests of the AMTB. However, the question of the Nonsense Words subtest remains. Aten and Davis (1968) found children with Minimal Cerebral Dysfunction (MCD) to score similarly to normal children on a nonsense word test. It might be hypothesized that LD children find all auditory STM material as confusing and lacking in cues as the Nonsense Words subtest. Therefore, their ability to handle "cue-less" material was comparable to normals. However, when they received stimuli that they should have been able to order, or categorize, or gain cues from, their performance became starkly different.

In further examining the scores for the LD children, it became apparent that span and sequence scores were identical for these children. This supported McCausland's statement that neither span nor sequence is better in differentiating LD from normal children. However, it points up a pertinent fact as noted by Aten and Davis (1968). These researchers stressed that one must examine the qualitative differences in the errors made by LD children. Normal children tended to leave out parts of the stimulus items or change the order of items. The latter instance caused the discrepancy between span and sequence scores. However, the LD children tested here made errors because they seemed unable to switch tasks, i.e., they carried over parts of stimulus items from the previous stimulus. They also added unrelated or extra parts to stimulus items. Such errors were merely counted incorrect rather than gaining partial credit as with the span scores. It would appear that errors of LD children are characterized by a complication or unusual altering of the stimulus, rather than a simplification of the stimulus as noted with normal children. 


\section{CHAPTER V}

\section{SUMMARY AND IMPLICATIONS}

\section{Summary}

This study examined the means and standard deviations for the Auditory Memory Test Battery (Burford, 1976) using a sample of normal 2nd, 3rd, and 4th grade children. The study also compared span and sequence scores, low and high SES scores, and an individual's test scores with teacher judgment of intelligence group. A brief examination of the AMTB as used with LD children was also performed but not included in the statistical analysis.

A total of seventy-five normal subjects were tested individualiy using the AMTB. The AMTB consisted of five tape recorded tests of recall for digits, related words, unrelated words, sentences, and nonsense words. Subjects responded verbally to randomly presented tests and each subject obtained ten scores: a span score and a sequence score for each of the five subtests. The possible score for each subtest was twentyeight points for both span and sequence. Two learning disabled children were also tested using the AMTB for comparative purposes.

The results of this investigation revealed a plateauing effect for auditory STM. Scores for 2 nd and 3rd graders were fairly equal while 4th graders scored better than the other two grade levels. A developmental change in auditory memory appeared to take place at the 4 th grade level. 
Answers to corollary questions revealed the following results. Scores for span were significantly better than scores for sequence among this group of normal children. Scores for children from a low SES were almost identical to scores for children from a high SES. A tendency for higher scores among those children judged to be of a "high" intelligence group was noted.

The two LD children tested scored well below the normal mean on all subtests except Nonsense. Words. Errors were qualitatively different from those of normal children.

\section{Implications}

Clinical Implications

As Miller (1956) demonstrated, the auditory STM is finite. It is limited to retaining approximately seven "bits" of information. The research of McCausland (1978), Aten and Davis (1968), and others have demonstrated that $L D$ children have deficits in this grouping ability. The present research offers support to this concept, even though the LD sample size was extremely smal1. A focus of treatment for LD children should therefore be the learning of cues and categorization. Predictive probability of occurence of various forms in the language should also be addressed.

The span versus sequence question for $L D$ and normal children remains an issue. Is there in fact a consistent difference between these two groups for span and sequence? Can such a difference be used to identify LD children? More research is needed so that a consensus might be reached.

Perhaps the most important clinical implication of this research 
is that the means and standard deviations for normal children have provided a benchmark for comparison. With further standardization, some or all of the AMTB may be used as a diagnostic test for learning disabled children.

Research Implications

As noted above, a research priority is the determination of group differences on scores for span and scores for sequence. A consistent result across a large experimental sample of LD and normal children is necessary.

Further research is also called for to determine the developmental growth of auditory STM. As discovered in this research, plateaus appeared to exist. Where are these plateaus along the developmental ladder? When do marked changes occur? Just how does the development of auditory STM in a LD child differ from that of a normal child? All of these questions need empirical answers.

A major research question this study posed was the determination of the exact qualitative differences of LD children's errors as opposed to those of normal children. Are the types of errors seen for the two LD children tested here characteristic of a large sample of LD children? An answer to the qualitative question will increase the diagnostic validity of auditory short-term memory testing. 


\section{SELECTED BIBLIOGRAPHY}

ACKERMAN, P., PETERS, J. and DYKMAN, R. Children with specific learning disabilities: WISC profiles. Journal of Learning Disabilities, $4: 150-166,1971$.

ATEN, J. and DAVIS, J. Disturbances in the perception of auditory sequence in children with Minimal Cerebral Dysfunction. Journal of Speech and Hearing Research, 11:236-245, 1968.

ATKINSON, R. and SHIFFRIN, R. The control of short-term memory. Scientific American, 225:82-90, 1971.

BERRY, M. Language Disorders of Children. Englewood Cliffs: Prentice-HaTT, 1969.

BURFORD, S. Auditory short-term memory span and sequence for five different stimulus types. Masters Thesis, Portland State University, 1976.

CARROW, E. and MAULDIN, M. Children's recall of approximations to English. Journal of Speech and Hearing Research, 16:201-212, 1973.

CASTEEL, R. Normal language development. Lecture presented at Portland State University, 1978.

CHALFANT, J. and SCHEFFELIN, M. Central Processing Dysfunctions in Children: A Review of Research. Bethesda: U.S. Department of Health, Education and Welfare, 1969.

CHAPOUTHIER, G. Behavioral studies of the molecular bas is of memory. In J. Deutsch (Ed.) The Physiological Basis of Memory. New York: Academic Press, 1973.

DREXLER, H. Application of distinctive feature analys is to articulation therapy. Lecture presented at Portland State University, 1974.

EIMAS, P. Distinctive feature codes in the short-term memory of children. Journal of Experimental Child Psychology, 19:241-251, 1975.

ELLIOTT, $C$. and STRAWHORN, R. Interference in short-term memory from vocalization: Aural versus visual modality differences. Journal of Experimental Child Psychology: Human Learning and Memory, $2: 702-711,1976$. 
FUGISAKI, H. and KAWASHIMA, T. Some experiments of speech perception and a model for the perceptual mechanism. Annual Report for the Engineering Research Institute (Toyko), $24: 207-214,1970$, cited by D. Pisoni, Auditory and phonetic memory codes in the discrimination of consonants and vowels. Perception and Psychophysics, 13:253$260,1973$.

HILGARD, E. and BOWER, G. Theories of Learning. (4th ed.) New York: Appleton-Century-Crofts, 1975.

HUNTER, I. Memory: Facts and Fallacies. Baltimore: Penguin Books, Inc., 1964.

IVERSEN, S. Brain lesions and memory in animals. In J. Deutsch (Ed.) The Physiological Basis of Memory. New York: Academic Press, 1973.

JOHNSON, D. and MYKELBUST, H. Learning Disabilities: Educational Principles and Practices. New York: Grune \& Stratton, 1967.

KIRK, S., McCARTHY, J. and KIRK, W. Illinois Test of Psycholinguistic Abilities. Champaign: University of Illinois Press, 1968.

McCARTHY, J. and McCARTHY, J. Learning Disabilities. Boston: Allyn and Bacon, 1969.

MCCAUSLAND, K. A comparative study of the short-term auditory memory span and sequence of language/learning disabled children and normal children. Masters Thesis, Portland State University, 1978.

MILLER, G. The magical number seven, plus or minus two. Psychological Review, 63:81-97, 1956.

MONSEES, E. Temporal sequence and expressive language disorders. Exceptional Children, 35:141-147, 1968.

MYKELBUST, H. and JOHNSON, D. Dyslexia in children. Exceptional Children, 29:14-17, 1962.

NEWCOMER, P. and HAMMILL, D. Psycholinguistics in the Schools. Columbus: Charles E. Merrill, 1976.

PENFIELD, W. and RASMUSSEN, T. The Cerebral Cortex of Man. New York: The Macmillan Company, 1955.

PIAGET, J. and INHELDER, B. Memory and Intelligence. New York: Basic Books, 1973.

PISONI, D. Auditory and phonetic memory codes in the discrimination of consonants and vowels. Perception and Psychophysics, 13:253-260, 1973. 
SCHOLES, R., RASBURY, W., SCHOLES, I. and DOWNING, K. Sentence comprehension and short-term memory: some developmental considerations Language and Speech, 19:80-86, 1976.

SCHULTER, G. Functional aspects of information processing in human memory. Psychological Research, 38:23-36, 1975.

SCHWALB, E., BLAU, H. and BLAU, H. Child with brain dysfunction. Journal of Learning Disabilities, 2:182-188, 1969.

SENF, G. and FREUNDL, P. Sequential auditory and visual memory in learning disabled children. Proceedings, 80th Annual Convention, American Psychological Association, 7:511-512, 1972.

SMITH, C. An experimental approach to children's linguistic competence. In J. Hayes (Ed.) Cognition and the Development of Language. New York: Wiley, 1970 .

STARK, J. A comparison of the performance of aphasic children on three sequencing tests. Journal of Communication Disorders, 1:31-34, 1967.

TURIADS, D., WEPMAN, J. and MORENCY, A. A perceptual test battery. Elementary School Journal, 72:351-361, 1972.

WECHSLER, C. Manual for the Wechsler Intelligence Scale for ChildrenRevised. New York: Psychological Corporation, 1974.

WEPMAN, J. and MORENCY, A. Manual of Administration, Scoring and Interpretation of the Auditory Sequential Memory Test. Chicago: Language Research Association, Inc., 1973.

WIIG, E. and SEMEL, E. Language Disabilities in Children and Adolescents. Columbus: Charles E. Merri11, 1976.

WITKIN, B. Auditory perception - Implications for language development. Language, Speech and Hearing Services in Schools, 2:31-51, 1971.

ZIGMOND, N. Auditory processes in children with learning disabilities. In L. Tarnopol (Ed.) Learning Disabilities. Springfield: Charles C. Thomas, 1969.

ZIGMOND, N. and CICCI, R. Auditory Learning. San Rafael: Dimensions Publications, 1968. 


\section{APPENDIX A}

\section{PARENT PERMISSION FORM}

$$
\text { April 16, } 1979
$$

\section{Dear Parent or Guardian:}

I am a Dortland State University graduate student doing a research project in Speech and Hearing Science. The Scappoose School District has giver me permission to use students in the 2nd, 3 rd, and 4 th grade classes from Watts, Warren, and Petersen Schools in my study. The study deals with memory in normal children. The children who are involved in the study will listen to tape recorded sequences of words and repeat. these :ronds back to me. This will take approximately 20 minutes for each chilt.

No rames vill be used in the written results of the study. The information will be madc available to the classroom teachers and to the speech clinician to help them in their programming.

I am requesting your permission and your child's permission for $\mathrm{him} / \mathrm{her}$ to be involved in my project. Please send the sigred form with. your child back to his/her teacher as soon as possible. Please answer the questions on the form. Thank you very much.

$$
\text { Sincerely, }
$$

Mary C. Mountain

\section{Date}

$$
I
$$
hereby permit

to act as a subject in Mary Mountain's study which is beirg done in the Scappoose School District.

*My child (has/has not) received remedial help in Speech/Language.

*My child (has/has not) recelved remedial help in Reading.

Parent's signature

$I$,

agree to be in Mary Mountain's study. 


\section{APPENDIX B}

RESPONSE FORM FOR AMTB

UNRELATED WORDS

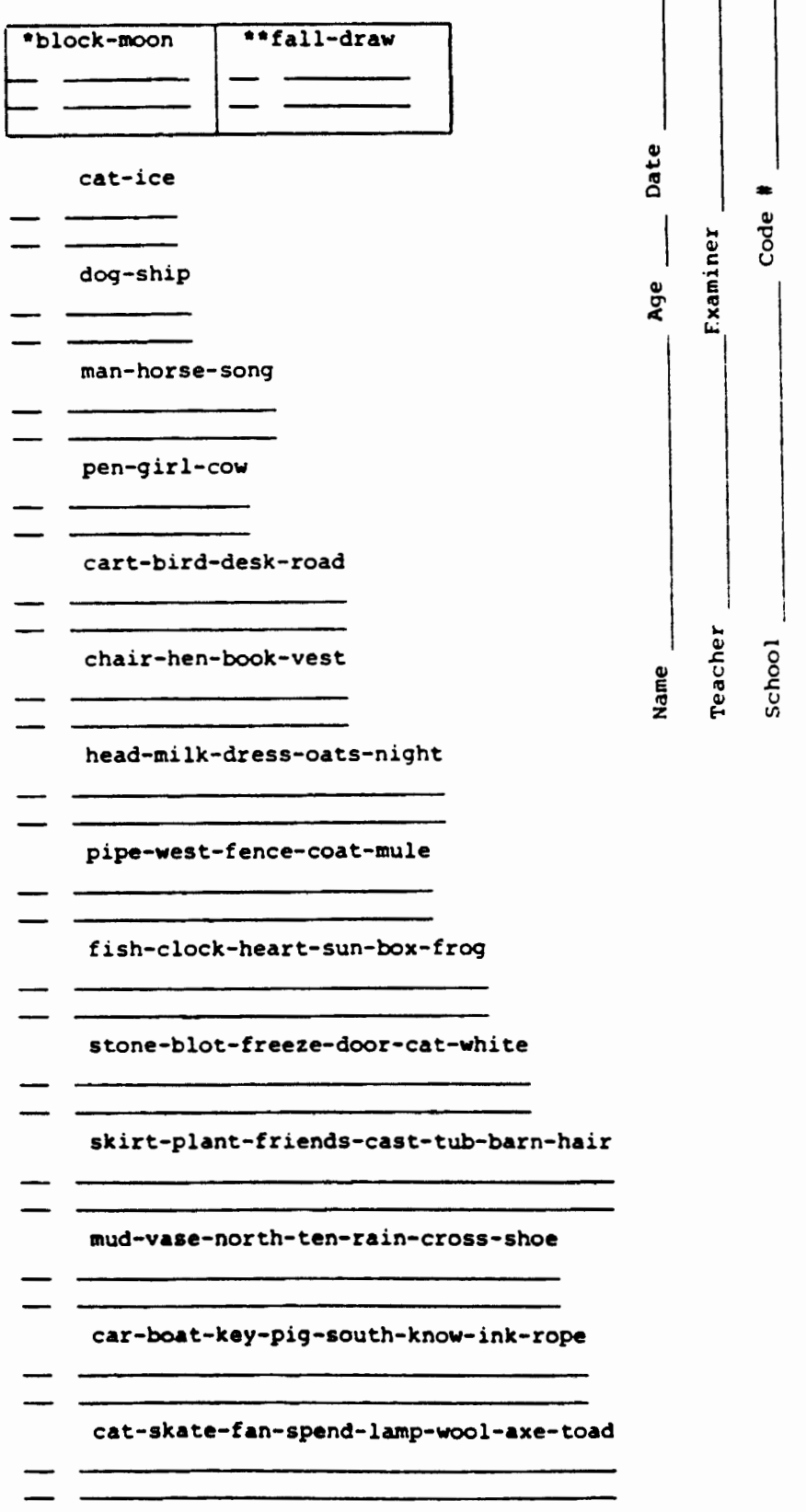


APPENDIX B CONT.

NONSENSE WORDS

\begin{tabular}{|cc|cc|}
\hline Jeb-dza & 1 & $*$ & /gorset-Am/ \\
-1 & 1 & 1 \\
-1 & 1 & -1 & 1 \\
\hline
\end{tabular}

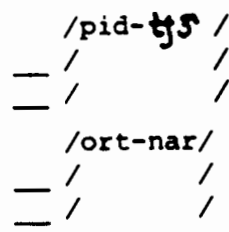

/pem-krsg-bran/
$-/$
$/$ taf-mus-sum/

$\begin{array}{ll}1 & 1 \\ -1 & 1\end{array}$

/tuf-1ndz-wep-dit/

$-1,1$

/ t5-ral-Sar-han/

$-1$

$/ \delta q-1 \varepsilon f-b o g-a b-r a z /$

$-1$

/fodg-hev-nzf-ak-fuz/

- '

/ Int-mat-atrop-grub-png-zg/

- 1 ,

/lan-ta-nip-18n-dssd-ka/

$\begin{array}{ll}1 & 1 \\ -1 & 1\end{array}$

/zar-sad-wam-f\&f-twan-bro-drat/

$-1,1$

/vo-do $\int-3 s-22 k-a z n-j o b-z u p /$

-1 1

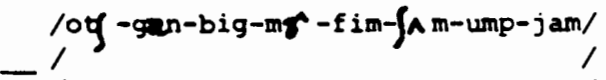

- 1

$/$ tran-2ab-myk-bem-wnmp-mif-t\&g-bup/
-1 
APPENDIX B CONT.

RELATED WORDS

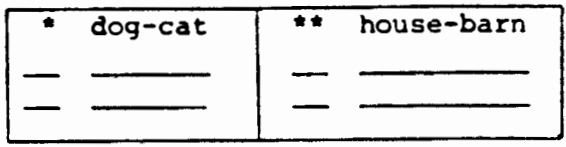

car-bus

$-\longrightarrow$

shoe-hat

-

cow-goat-horse

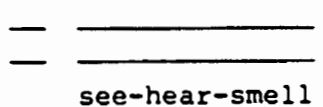

see-hear-smell

-

chair-lamp-couch-rug

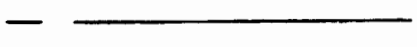

eye-hand-ear-nose

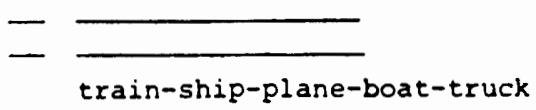

-

rain-hail-ice-snow-sleet

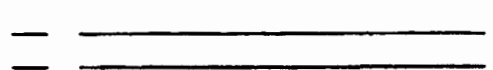

talk-yell-scream-cry-shout-sigh

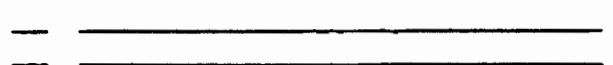

socks-tie-belt-coat-shirt-pants

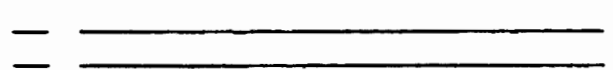

bowl-plate-spoon-cup-fork-glass-knife
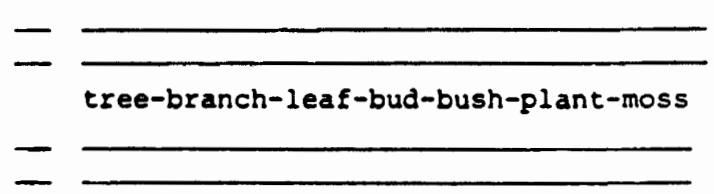

meat-corn-pie-milk-egg-soup-bread-peach

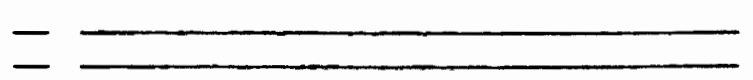

blue-green-pink-black-brown-red-grey-white

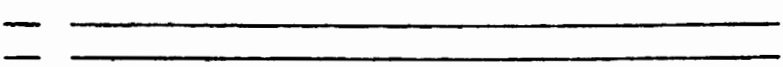




\section{APPENDIX B CONT.}

DIGITS

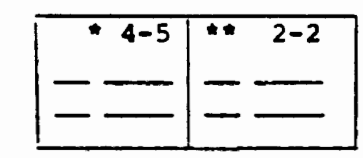

9-1

$-\frac{}{2-9}$

$-\frac{}{8-1-1}$

$-\overline{6-4-9}$

$-\frac{}{2-8-3-3}$

$-\overline{\text { 6-3-5-1 }}$

$-\longrightarrow$

- $\overline{4-3-3-9-9}$

$-\frac{}{6-1-4-2-8}$

$-\frac{}{8-4-8-3-5-5}$

$-\overline{2-9-6-1-8-3}$

$-\frac{}{3-6-1-9-2-3-9}$
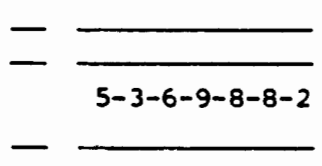

-

$3-2-9-2-3-4-8-8$

$-\frac{}{9-6-3-8-5-1-2-2}$

-
SENTENCES

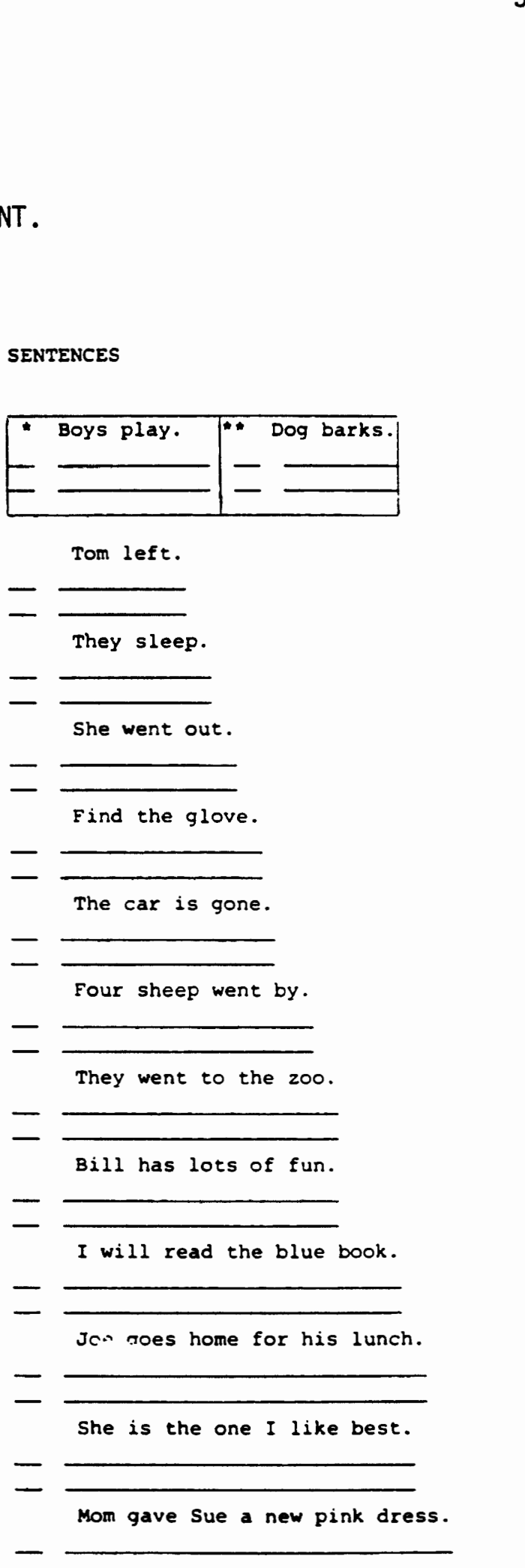

Tom left.

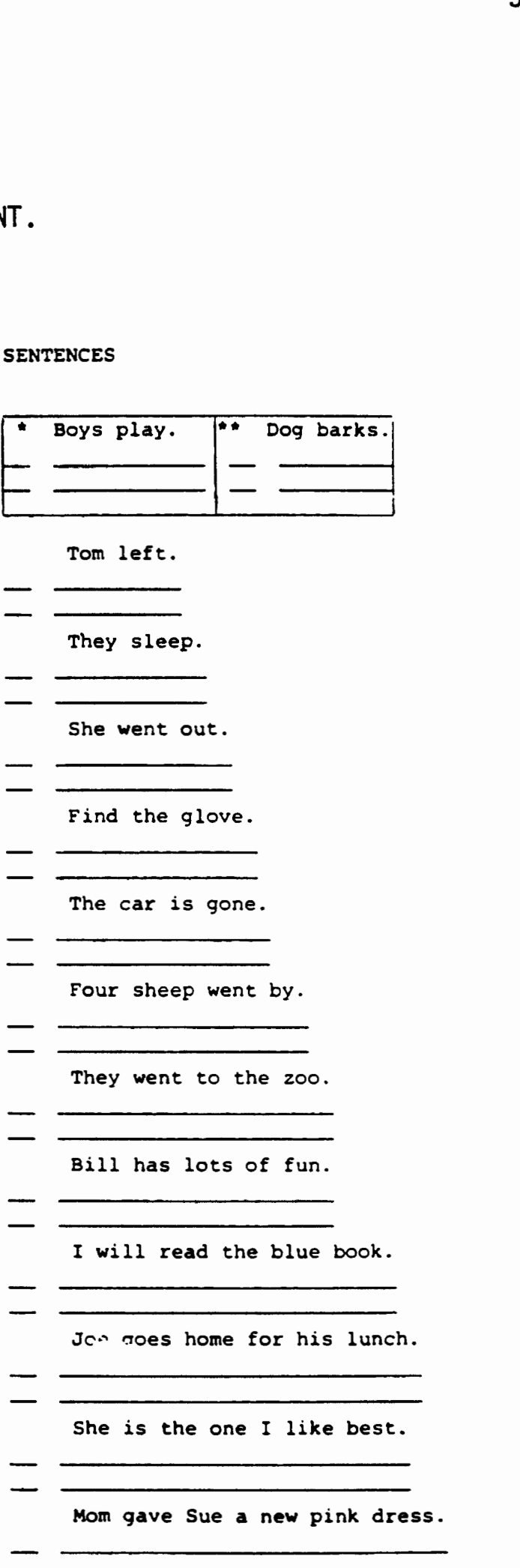

$-\overline{\text { She went out. }}$

- $\overline{\text { Find the glove. }}$

-

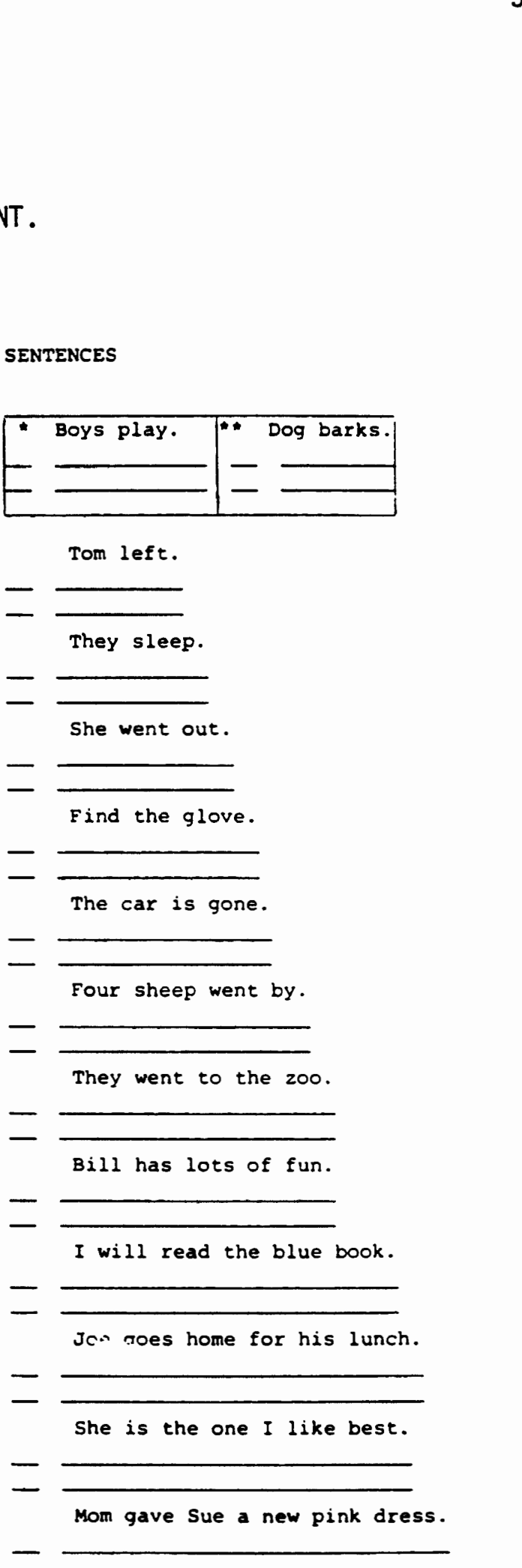

Four sheep went by.
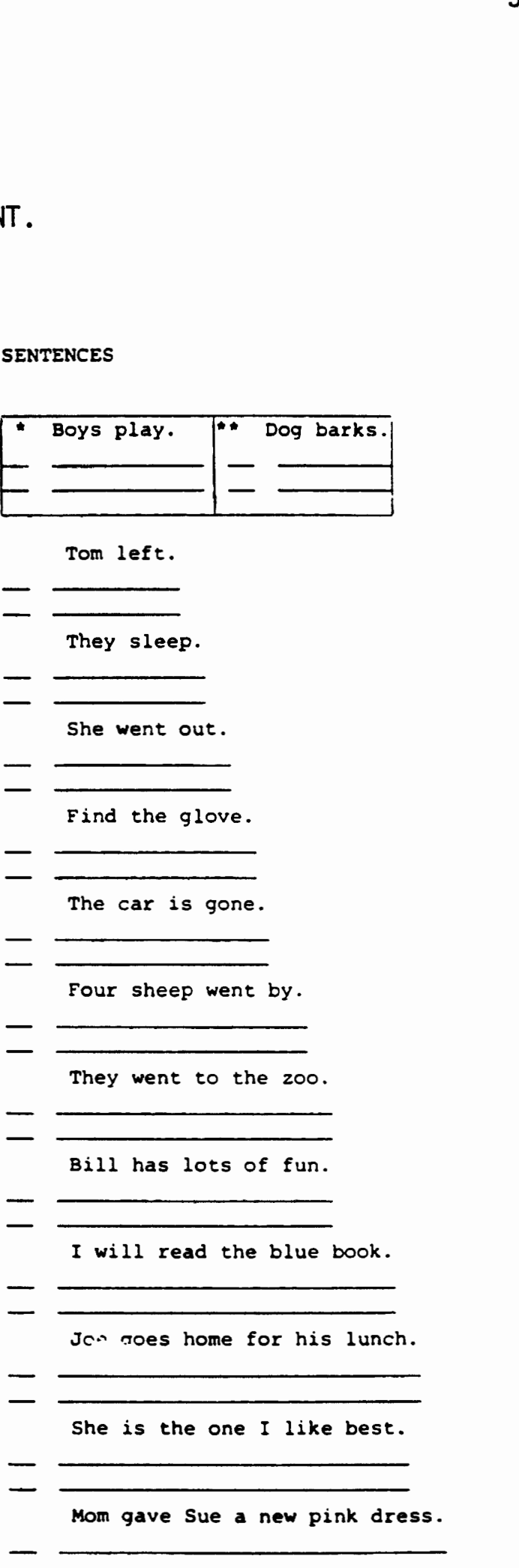

Bill has lots of fun.
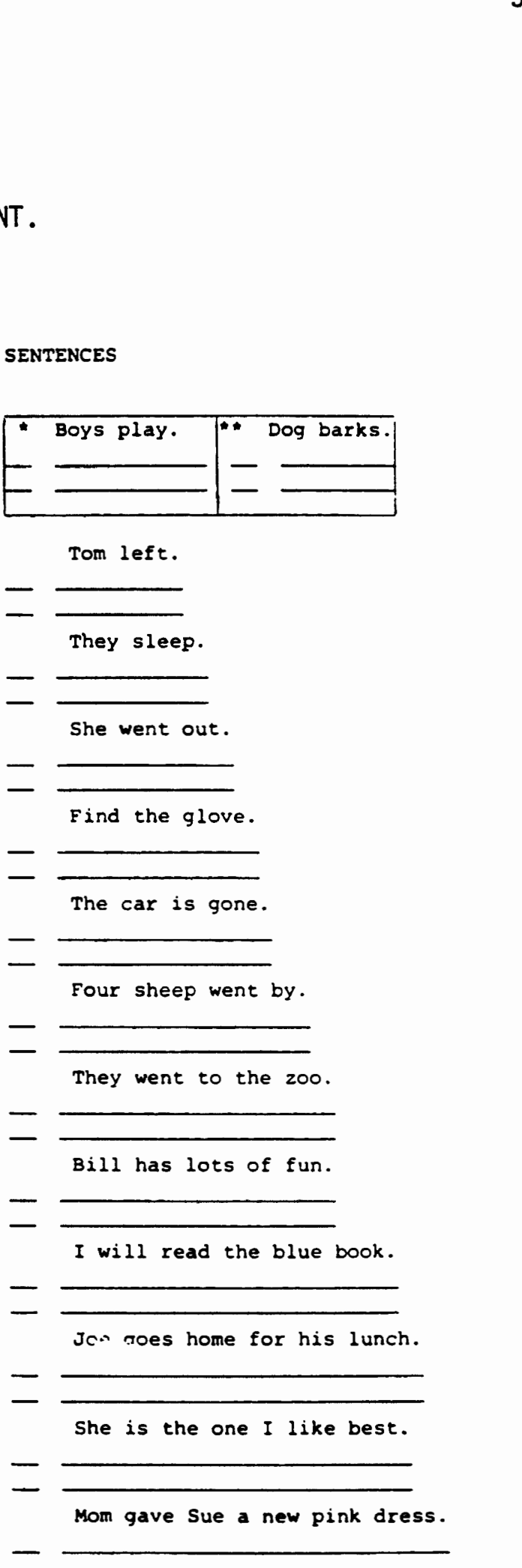

Sam likes to play with his big dog.

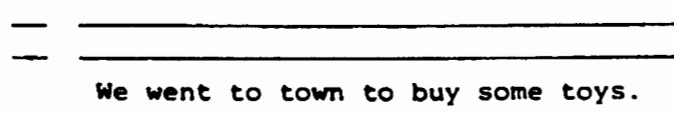




\section{APPENDIX C}

SUBTEST RANDOMIZING LIST

1. 54213

2. 42531

3. 34125

4. 43251

5. 21435

6. 51243

7. 41253

8. 34251

9. 42351

10. 43512

11. 43215

12. 14251

13. 25341
14. 41235

15. $\quad 13524$

16. 42523

17. 32145

18. $\quad 35124$

19. 51423

20. 12345

21. 45132

22. 21453

23. 42351

24. 31245

25. 13452 
APPENDIX D

DISTINCTIVE FEATURE GRID

RELEASES SYLLABLE

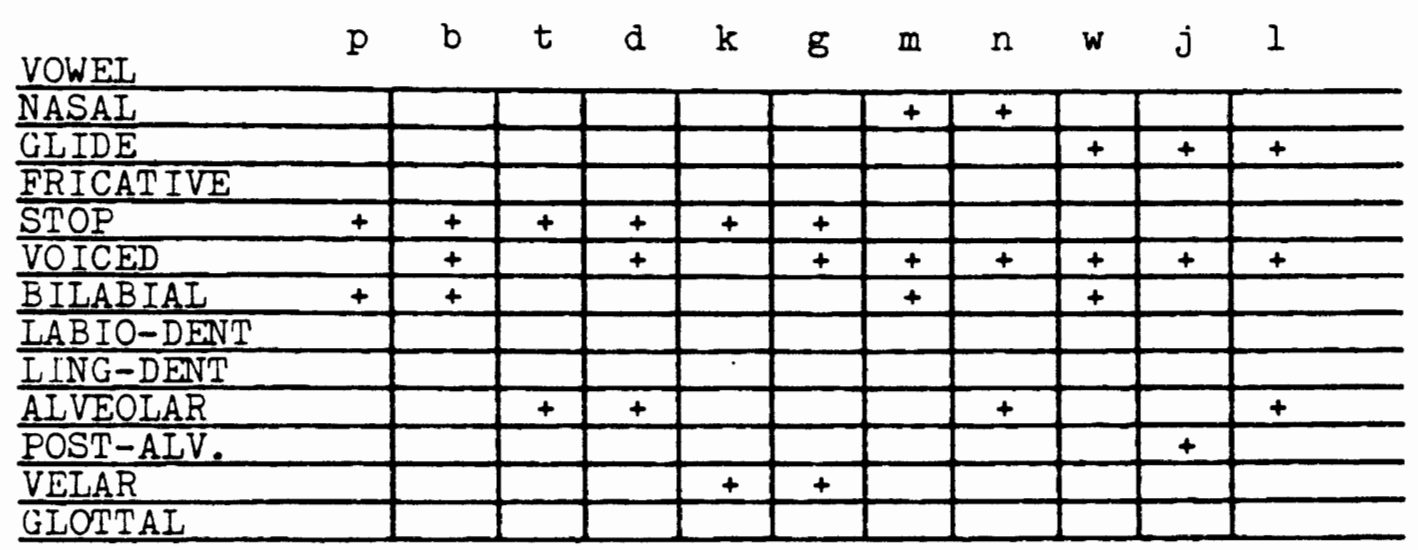

\begin{tabular}{|c|c|c|c|c|c|c|c|c|c|c|c|}
\hline VOWEL & r & $f$ & $\mathrm{v}$ & $\theta$ & $\widetilde{\gamma}$ & s & $z$ & $S$ & $d z$ & t & $\mathrm{h}$ \\
\hline \multicolumn{12}{|l|}{ NASAL } \\
\hline \multicolumn{12}{|l|}{ GLIDE } \\
\hline FRICATIVE & & + & + & + & + & + & + & + & + & + & \pm \\
\hline STOP & & & & & & & & & + & + & \\
\hline VOICED & + & & 4 & & + & & + & & + & & \\
\hline \multicolumn{12}{|l|}{ BIIABIAI } \\
\hline IABIO-DENT & & + & + & & & & & & & & \\
\hline IING-DENT & & & & + & + & & & & & & \\
\hline AIVEOLAR & & & & & & + & + & & & & \\
\hline POST-AIV. & + & & & & & & & + & + & + & \\
\hline \multicolumn{12}{|l|}{ VEIAR } \\
\hline GLOTTAL & & & & & & & & & & & + \\
\hline
\end{tabular}

(Drexler, 1974) 
APPENDIX D CONT.

DISTINCTIVE FEATURE GRID

ARRESTS SYLLABLE

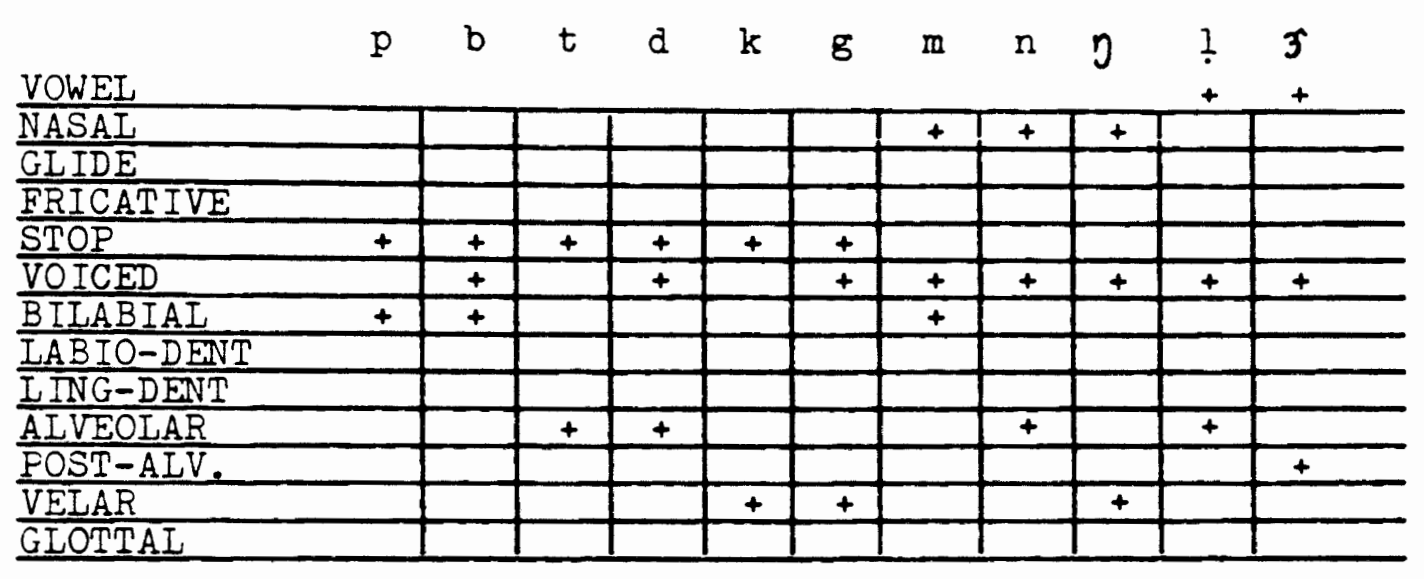

\begin{tabular}{|c|c|c|c|c|c|c|c|c|c|c|c|}
\hline VOWEL & f & $\mathrm{v}$ & $\theta$ & ঋ & $\mathbf{s}$ & $\mathbf{z}$ & S & 3 & t5 & d3 & \\
\hline \multirow{2}{*}{\multicolumn{12}{|c|}{$\frac{\text { NASAL }}{\text { GIIDE }}$}} \\
\hline & \multicolumn{11}{|c|}{ GLIDE } \\
\hline FRICATIVE & \pm & + & + & \pm & \pm & + & + & \pm & + & + & \\
\hline STOP & & & & & & & & & + & + & \\
\hline \multirow{2}{*}{\multicolumn{12}{|c|}{ BILABIAI }} \\
\hline & & & & & & & & & & & \\
\hline LABIO-DENT & \pm & \pm & & & & & & & & & \\
\hline LING-DENT & & & + & \pm & & & & & & & \\
\hline ALVEOLAR & & & & & 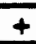 & + & & & & & \\
\hline POST-ALV. & & & & & & & \pm & + & \pm & \pm & \\
\hline VELAR & & & & & & & & & & & \\
\hline GLOTTAL & & & & & & & & & & & \\
\hline
\end{tabular}

